\title{
Identification of a general light use efficiency model for gross primary production
}

\author{
J. E. Horn ${ }^{1, *}$ and K. Schulz ${ }^{1}$ \\ ${ }^{1}$ Department of Geography, Ludwig-Maximilians-Universität München, Luisenstr. 37, 80333 Munich, Germany \\ * now at: Institute of Photogrammetry and Remote Sensing, Karlsruhe Institute of Technology (KIT), Kaiserstr. 12, \\ 76131 Karlsruhe, Germany
}

Received: 29 September 2010 - Published in Biogeosciences Discuss.: 22 October 2010

Revised: 11 March 2011 - Accepted: 21 March 2011 - Published: 21 April 2011

\begin{abstract}
Non-stationary and non-linear dynamic time series analysis tools are applied to multi-annual eddy covariance and micrometeorological data from 44 FLUXNET sites to derive a light use efficiency model for gross primary production on a daily basis. The extracted typical behaviour of the canopies in response to meteorological forcing leads to a model formulation allowing for a variable influence of the environmental drivers temperature and moisture availability modulating the light use efficiency. Thereby, the model is applicable to a broad range of vegetation types and climatic conditions. The proposed model explains large proportions of the variation of the gross carbon uptake at the study sites while the optimized set of six parameters is well defined. With the parameters showing explainable and meaningful relations to site-specific environmental conditions, the model has the potential to serve as basis for general regionalization strategies for large scale carbon flux predictions.
\end{abstract}

\section{Introduction}

The atmosphere and the terrestrial biosphere are tightly coupled through the exchange of energy and matter (Monteith and Unsworth, 2008). A central component of this coupling is the assimilation and release of $\mathrm{CO}_{2}$ by photosynthesis and respiration; these opposed fluxes modulate substantially the global carbon cycle (Schimel et al., 2001). The rising $\mathrm{CO}_{2}$ concentration in the atmosphere and the associated changing climate factors have implications on the functioning of ecosystems and hence provoke a feedback on the carbon cycle in turn (Cox et al., 2000).

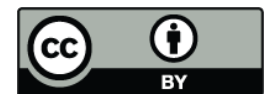

Correspondence to: J. E. Horn (judith.horn@kit.edu)
Consequently, quantifying the global carbon balance under current conditions and predicting its characteristics in a future environment with enhanced atmospheric $\mathrm{CO}_{2}$ concentrations implies the quantification of $\mathrm{CO}_{2}$ uptake and respiration rates of ecosystem as well as descriptions of their main drivers (Cramer et al., 2001). With plants trading water vapour with $\mathrm{CO}_{2}$, the $\mathrm{CO}_{2}$ assimilation additionally has effects on the hydrologic cycle, another global key cycle in a changing environment (Law et al., 2002; Jackson et al., 2005; Barr et al., 2007).

The biochemical and biophysical processes of photosynthesis and respiration as principle processes in ecosystems have been studied extensively under laboratory conditions and are well understood on cell, leaf and plant scales (Farquhar et al., 1980; Stitt, 2006). Sophisticated process models of carbon fluxes formulated at these scales are incorporated into soil-vegetation-atmosphere transfer model schemes (Collatz et al., 1991), which have more and more often found their way in GCMs (global circulation models, Cox et al., 1998; Sellers et al., 1997). However, the upscaling in time and space from a cell, leaf and plant scale to regional dimensions is not straightforward (Leuning et al., 1995). Furthermore, these complex models need many detailed input parameters which are often not measurable or not available at canopy or regional scales, a fact rendering model predictions uncertain (Wang et al., 2001; Franks et al., 1997; Schulz et al., 2001; Beven and Freer, 2001). An alternative strategy to circumvent some of these difficulties is the specific development of process models for regional scale and inter-seasonal or inter-annual purposes. Biosphere models like Biome-BGC (Running and Hunt, 1993) or BETHY (Knorr, 2000) with daily time steps were designed with the compromise between mechanistic details and simplified process description. Still, these models are subject to uncertainty in process parameters; studies have revealed that even these

Published by Copernicus Publications on behalf of the European Geosciences Union. 
models developed in a process and scale integrating manner show an imbalance between the input data requirements and the actual information content of measurement data which enhances the forecast uncertainty significantly (Knorr and Heimann, 2001a,b; Zaehle et al., 2005; White et al., 2000). A frequently tested possible solution for this dilemma are data assimilation schemes to further constrain these models (Kaminski et al., 2002; Knorr and Kattge, 2005; Rayner et al., 2005; Williams et al., 2004). This tactic has been made feasible by a growing number of ecosystem observation networks such as FLUXNET, satellite driven programs from ESA or NASA and integrative platforms like NESDIS (National Environmental Satellite, Data and Information Service).

Some studies go even further to overcome the restrictions of lacking information content in the available data to constrain model processes and to make the quantification of gross primary productivity better applicable for larger scales and chose very parsimonious model structures without the implementation of explicit physiological processes occurring at cell and leaf scale. Such models treat canopies as functional units aggregating and averaging processes over space and time. A very popular approach uses the concept of light use efficiency. The light use efficiency, $\epsilon$, represents the ratio of carbon biomass production per unit of absorbed light (Watson, 1947; Monteith, 1972; Monteith and Unsworth, 2008). Various studies have proven the light use efficiency $\epsilon$ to be quite constant over the day, a fact which renders the light use efficiency concept suitable for daily-step models (Ruimy et al., 1995; Rosati and Dejong, 2003; Sims et al., 2005). The light use efficiency parameter has been implemented in ecosystem models as a constant (Landsberg and Waring, 1997; Veroustraete et al., 2002) or as time-varying parameter. In the latter case, global or biome-specific maximum or potential light use efficiency is modified by one or more restricting environmental factors such as temperature and vapour pressure deficit with predefined functions (Potter et al., 1993; McMurtrie et al., 1994; Prince et al., 1995; Veroustraete et al., 2002; Xiao et al., 2004a; Yuan et al., 2007; Mäkelä et al., 2008). The LUE approach has been used as a stand-alone application (Yuan et al., 2007; Mäkelä et al., 2008) as well as integrated in ecosystem models (Coops et al., 2005), it has been driven with ground measurement data as well as combined with remote sensing data (Potter et al., 1993; Law and Waring, 1994; Prince et al., 1995). The MODIS-GPP algorithm (Running et al., 1999; Zhao et al., 2005 ) is principally based on the light use efficiency approach, too.

But despite numerous models proposed, many questions have remained unanswered and primary production modelling on landscape scale is still "an active area of research" (Hilker et al., 2008, p.418). Garbulsky et al. (2010) states that the relationships between the light use efficiency and its climatological drivers for different biomes are still not clarified, and, furthermore, "a substantial number of those relationships were derived from models rather than using evidence from actual measurements" (Garbulsky et al., 2010, p.254). The usage of fixed, biome specific maximum/potential light use efficiencies (such as in the MOIDS GPP algorithm) or even global constants (such as in the model proposed by Yuan et al., 2007) "is far from optimum and is the possible cause of the low performance of the photosynthetic uptake models" (Garbulsky et al., 2010, p.255). In this study, we address the discussed drawbacks of existing approaches and explore the benefits of applying a data-based modeling approach, which leads to a parsimonious model, which is subsequently site-specifically parametrized.

Basic relationships like the light use efficiency are well suited as a starting point for model identification procedures in a top-down fashion. Such methodologies try to develop models specifically at the scale of interest beginning with the most robust functional relationships which are iteratively refined according to data analysis results. No a priori assumptions beside very basic functional relationships are made. In this way, observed data is given more weight in the model building process than in purely mechanistic based model building approaches without disregarding the robust mechanistic processes. This leads to hybrid stochastic-mechanistic models with not more complexity than can be supported by the observation data information content. Suitable tools for this methodology are - amongst others - non-parametric state-dependent parameter estimation (SDP) and dynamic linear regression (DLR) based on Kalman filtering and smoothing techniques. They allow for the time and state dependent evolution of parameters to be estimated directly from time series data (Young and Pedegral, 1999; Young et al., 2001) and have shown to be capable of capturing seasonal behaviour of ecosystems (Young, 1998; Schulz and Jarvis, 2004; Jarvis et al., 2004; Gamier, 2006; Taylor et al., 2007).

Apparently, the described approach relies on the existence of suitable data sets. Indeed, the growing number of micrometeorological and flux measurements in the FLUXNET framework makes such data-led model identification procedures more feasible than ever. FLUXNET (Baldocchi et al., 2001) is a global research network of currently over 400 eddy covariance towers which measure the exchange of energy, water vapour and $\mathrm{CO}_{2}$ along with important micrometeorological variables. This long-term measurement effort provides valuable insights into the functioning of ecosystems (Friend et al., 2007).

In what follows we use SDP and DLR to derive simple but - in contrast to many models published earlier - broadly applicable canopy-scale model structures for GPP on the basis of the light use efficiency concept. SDP is employed as diagnostic tool to identify the dominant behaviour of the light use efficiency in relation to the drivers under consideration in an objective manner. The noise inherent to the data is explicitly addressed. Therefore it is superior to a mere plotting of the light use efficiency (as coefficient of the absorbed radiation 
and the gross primary production) vs. the potential drivers. The such derived relationships form the basis for the subsequent formulation of the subfunctions modifying the maximum light use efficiency. Such an approach has already been applied by Jarvis et al. (2004) for two deciduous forest sites. They extracted a sigmoidal functional form for the light use efficiency depending on the lagged soil temperature. Here, we want to enhance this study to more sites and different vegetation and climate classes. As will be seen, this makes it necessary to refine the found model structures by Jarvis et al. (2004) - in the following called the "Jarvis-model" and to account for additionally forcing moisture availability proxies. The model parameters are calibrated site specifically following the assumption that there is no single set of parameters that describes the behaviour of sites across climate classes and vegetation types. Finally, found parameters are tested for patterns which relate themselves to site specific characteristics serving - as a first step - the final aim to regionalize the model parameters.

\section{Data and methods}

\subsection{Micro-meteorological data}

44 forest and grassland FLUXNET sites in climate zones reaching from boreal to semi-arid were chosen as data base for this study (Table 1). The selection criterion was the existence of at least three measurement years and no measurement gaps longer than three weeks with respect to the core variables $\left(\mathrm{CO}_{2}\right.$, radiation and temperature). The selected sites are located in North America and Europe comprising 12 coniferous forest sites, 18 deciduous, 5 mixed, 2 evergreen forests as well as 7 grasslands. Table 1 summarizes their characteristics. The data were downloaded from the web gateways of the regional FLUXNET sub-networks AmeriFlux and CarboEurope as hourly and half-hourly data. As there is still an ongoing debate on whether and how to apply friction velocity filtering of measured surface fluxes (Falk et al., 2005; Papale et al., 2006; Acevedo et al., 2009), we follow Jarvis et al. (2004) in using the complete data-set. Being aware of the potential of thereby introducing a slight bias (Papale et al., 2006), this does not limit our derived results. The downloaded data including energy and carbon fluxes along with meteorological variables have measurement gaps which were filled in the following way: Short gaps up to three hours of meteorological variables are linearly interpolated. The average values of the respective values at the time of day in a 14-day moving time window around the gap (Falge et al., 2001) serve to fill gaps of medium length up to 4 days. Even larger gaps are replaced with the respective values averaged over the whole time series available. Missing data in the time series of $F_{\mathrm{N}}$ are replenished on the hourly time scale with the multidimensional semi-parametric spline interpolation scheme explained in Stauch and Jarvis (2006).
This method forms a multi-dimensional spline-hypersurface through the measured data in a space spanned by the temperature, radiation and time. Thereby, the method is similar to a three-dimensional look-up table approach which avoids a binning of the data, or it can be seen as "a nonlinear regression without a prescribed functional form" (Desai et al., 2008, p.823). The methodology compares well to other gap-filling techniques for eddy covariance net carbon fluxes (Moffat et al., 2007). The gap-filled net flux was finally split up into respiration and the gross flux component, $F_{\mathrm{G}}$, by using the hypersurface through the night-time values to determine the respiration component. The gross flux of carbon uptake $\left(F_{\mathrm{G}}\right)$ was afterwards calculated as difference of net flux and respiration (Desai et al., 2008). Finally, all time series of the meteorological and flux variables were aggregated to time series with daily values: Climatological variables were averaged, fluxes summed up. These time series with daily time steps are used throughout the following study.

\subsection{MODIS LAI/FPAR product}

The absorbed photosynthetically active radiation (APAR) is a core input variable of typical light use efficiency models and as such used in this study, too. It is the product of the incident photosynthetically active radiation (PAR) and the fraction of photosynthetically active radiation absorbed by the plants (FPAR). The latter variable was downloaded as MODIS LAI/FPAR Land Products subset Oak Ridge National Laboratory Distributed Active Archive Center (ORNL DAAC) for each study site. These MOD15A2 and MYD15A2 subsets provide 8-day values in a grid of $7 \times 7$ pixels with a size of $1 \mathrm{~km}^{2}$ centred on the tower. MOD15A2 and MYD15A2 are produced with data from the satellites Terra and Aqua and are retrieved by inverse radiative transfer modeling (Knyazikhin et al., 1999). In this study, the products from both satellites were merged into one dataset according to Yang et al. (2006). For forests, each of the 49 pixels with the same land class as the study site according to the MODIS product MOD12Q1 is taken into account for this study; for grasslands, only the $3 \times 3$ pixels around the tower are considered. Taking more than the center pixel into account is a typical approach (Leuning et al., 2005; Xiao et al., 2008). If neither Terra nor Aqua delivered a value with the main algorithm the mean of all available years at the considered day of year was taken instead. To calculate the average of the several pixels at each time step, the values were weighted according to their inverse difference to the multi-annual mean of FPAR values for the whole subset at the particular day over all measurement years, since the values of the neighbouring pixels often differ significantly from each other with sometimes unrealistic values. Due to this noisiness of the MODIS LAI/FPAR time series (Gu et al., 2006b; Gao et al., 2008; Horn and Schulz, 2010) and the need to temporally disaggregate the time series composed of 8-day-values into a daily time steps, the 
Table 1. Name, vegetation (veg.) and climate class, measurement years utilized in this study, and reference for the study sites. KoeppenGeiger-climate classes: steppe climate (BS), temperate (C), continental (D); summer dry (s), fully humid (f); hot (h), cold in winter (k); hot summer (a), warm summer (b), cool summer (c), cold winter (d); vegetation types: deciduous broadleaf forest (DBF), mixed (MF), evergreen needleleaf (ENF), evergreen broadleaf (EBF), grass $(\mathrm{G})$.

\begin{tabular}{|c|c|c|c|c|}
\hline Name & veg. & climate & year & reference \\
\hline Black Hills (US-Blk) & ENF & Dfa & 2004-2006 & Wilson and Meyers (2007) \\
\hline Blodgett (US-Blo) & ENF & $\mathrm{Csb}$ & 2002-2006 & Goldstein et al. (2000) \\
\hline Boreas (CA-Man) & ENF & Dfc & $1995-2005$ & Goulden et al. (2006) \\
\hline Donaldson (US-SP3) & ENF & $\mathrm{Cfa}$ & 2001-2004 & Gholz and Clark (2002) \\
\hline Flakaliden (SE-Fla) & ENF & Dfc & 2000-2002 & Wallin et al. (2001) \\
\hline GLEES (US-GLE) & ENF & Dfc & 2006-2008 & Massman and Clement (2005) \\
\hline Griffin (UK-Gri) & ENF & $\mathrm{Cfb}$ & 1998, 2000-2001 & Clement et al. (2003) \\
\hline Hyytiälä (Fl-Hyy) & ENF & Dfc & $1997-2006$ & Suni et al. (2003) \\
\hline Le Bray (FR-LBr) & ENF & $\mathrm{Cfb}$ & $2001-2003$ & Berbigier et al. (2001) \\
\hline Loobos (NL-Loo) & ENF & $\mathrm{Cfb}$ & 1997-2006 & Dolman et al. (2002) \\
\hline Metolius Interm. (US-Me2) & ENF & $\mathrm{Csb}$ & 2002-2005, 2007 & Anthoni et al. (2002) \\
\hline Metolius Young (US-Me5) & ENF & $\mathrm{Csb}$ & 2002-2002 & Anthoni et al. (2002) \\
\hline Niwot Ridge (US-NR1) & ENF & Dfc & 1999-2006 & Sacks et al. (2006) \\
\hline Norunda (SE-Nor) & ENF & Dfb & $1996-2005$ & Lagergren et al. (2005) \\
\hline Tharandt (DE-Tha) & ENF & $\mathrm{Dfb}$ & $1997-2003$ & Grünwald and Bernhofer (2007) \\
\hline Wetzstein (DE-Wet) & ENF & $\mathrm{Dfb}$ & $2002-2008$ & Rebmann et al. (2010) \\
\hline Wind River (US-Wrc) & ENF & $\mathrm{Csb}$ & 1999-2004, 2006 & Shaw et al. (2004) \\
\hline Yatir (IL-Yat) & ENF & BSh & $2001-2002,2005$ & Maseyk et al. (2008) \\
\hline Bartlett (US-Bar) & $\mathrm{DBF}$ & Dfc & 2004-2007 & Jenkins et al. (2007) \\
\hline Duke Hardwood (US-Dk2) & DBF & $\mathrm{Cfa}$ & $2001-2005$ & Stoy et al. $(2005,2007)$ \\
\hline Hainich (DE-Hai) & $\mathrm{DBF}$ & $\mathrm{Dfb}$ & $2000-2007$ & Mund et al. (2010) \\
\hline Hesse (FR-Hes) & $\mathrm{DBF}$ & $\mathrm{Cfb}$ & 1997-2007 & Granier et al. (2008) \\
\hline MMSF (US-MMS) & $\mathrm{DBF}$ & Dfa & 1999-2006 & Schmid et al. (2000) \\
\hline Missouri Ozark (US-MOz) & DBF & Dfa & $2005-2008$ & Gu et al. (2006a, 2007) \\
\hline Roccarespampani (IT-Ro1) & DBF & Csa & $2001-2003$ & Keenan et al. (2009) \\
\hline Soroe (DK-Sor) & DBF & $\mathrm{Cfb}$ & $1997-2005$ & Pilegaard et al. (2003) \\
\hline Sylvania Wilderness (US-Syv) & DBF & $\mathrm{Dfb}$ & 2002-2004 & Desai et al. (2005) \\
\hline UMBS (US-UMB) & DBF & $\mathrm{Dfb}$ & 1999-2003 & Gough et al. (2008) \\
\hline WalkerBranch (US-WBW) & DBF & $\mathrm{Cfa}$ & 1995-1999 & Wilson and Meyers (2007) \\
\hline Willow Creek (US-WCr) & $\mathrm{DBF}$ & $\mathrm{Dfb}$ & $2000-2006$ & Cook et al. (2004) \\
\hline Castelporziano (IT-Cpz) & $\mathrm{EBF}$ & Csa & $2002-2003$ & Seufert et al. (1997) \\
\hline Puechabon (FR-Pue) & $\mathrm{EBF}$ & $\mathrm{Csb}$ & 2001-2008 & Allard et al. (2008) \\
\hline Audubon (US-Aud) & G & $\mathrm{BSh}$ & 2004-2008 & Wilson and Meyers (2007) \\
\hline Goodwin Creek (US-Goo) & $\mathrm{G}$ & $\mathrm{Cfa}$ & 2004-2006 & Wilson and Meyers (2007) \\
\hline Lethbridge (CA-Let) & $\mathrm{G}$ & Dfb & 1999-2004 & Flanagan (2009) \\
\hline Neustift (AT-Neu) & $\mathrm{G}$ & $\mathrm{Dfb}$ & $2002,2005-2007$ & Wohlfahrt et al. (2008) \\
\hline Oensingen (CH-Oe1) & G & $\mathrm{Dfb}$ & $2002-2007$ & Ammann et al. (2009) \\
\hline Peck (US-FPe) & $\mathrm{G}$ & BSk & $2000-2006$ & Wilson and Meyers (2007) \\
\hline Vaira Ranch (US-Var) & $\mathrm{G}$ & Csa & $2001-2007$ & Ma et al. (2007) \\
\hline Brasshaat (BE-Bra) & MF & $\mathrm{Cfb}$ & $1997-2008$ & Carrara et al. $(2003,2004)$ \\
\hline Duke (US-Dk3) & MF & $\mathrm{Cfa}$ & 1999-2002 & Siqueira et al. (2006) \\
\hline Harvard (US-Ha1) & MF & $\mathrm{Dfb}$ & 1992-2007 & Urbanski et al. (2007) \\
\hline Howland (US-Ho3) & MF & $\mathrm{Dfb}$ & 1996-2004 & Hollinger et al. (2004) \\
\hline Vielsalm (BE-Vie) & MF & $\mathrm{Cfb}$ & $2000-2008$ & Aubinet et al. (2001) \\
\hline
\end{tabular}

final FPAR time series was retrieved by a cubic smoothing spline fitted through all data points as described in Horn and Schulz (2010). APAR was finally calculated as product of PAR measured at the FLUXNET sites and FPAR.

\subsection{Data analysis and pre-processing methods}

The study of Jarvis et al. (2004) proved non-stationary regression frameworks such as the "Captain Toolbox" for Matlab $^{\circledR}$ (Pedregal et al., 2007) to be perfectly suited to 
extract functional descriptions for the typical seasonal evolution of the respiration and gross carbon flux $\left(F_{\mathrm{G}}\right)$ from eddy covariance measurements as part of a model building process. These time series do not only depend on environmental conditions in a complex manner, but they are also afflicted with noise. This can hinder a simple signal extraction directly from the time series without filtering and smoothing techniques. Therefore, two of the toolbox's powerful tools, which are based on recursive Kalman filtering and fixed interval smoothing techniques, were employed both in the aforementioned study and are used in this study, too, as diagnostic tools: dynamic linear regression, DLR, and especially state dependent parameter analysis, SDP. They allow the extraction of systematic trends in the variation of nonconstant model parameters directly from measured time series and, hence, enable the objective identification of nonstationarities or state dependencies characterizing these timevarying parameters (Jarvis et al., 2004).

In particular, the underlying regression type in case of DLR is of the form

$y(t)=\sum_{i=1}^{n} c_{i}(t) \cdot x_{i}(t)+\zeta(t)$

where $y$ is the dependent variable, $x_{i}(t)$ are the regressors, $c_{i}$ are time $(t)$ dependent regression parameters and $\zeta(t)$ is the regression error series assumed to be a serially uncorrelated white noise sequence with a zero mean (Young and Pedegral, 1999). $i$ is the increment running from 1 to the number of regressors, $n$. DLR extracts the incremental temporal variations in $c$ assuming the parameters to gradually vary with time. The stochastic random walk process follows a white noise sequence $(\eta(t))$ with a zero mean (Jarvis et al., 2004). Each sampling instant depends on the data in its vicinity. A Gaussian weighting function determines the influence of the neighboring data samples on the one currently considered. The "bandwidth" of this Gaussian window function centered at the $i$-th sample instant and declining at either side is determined by the noise-variance ratio (NVR). The NVR is calculated as ratio of the variances of $\eta(t)$ and $\zeta(t)$ (Schulz and Jarvis, 2004). A NVR of zero corresponds to constant parameter values. Large NVR values imply a sharp decrease of the weighting function with increasing distance from the considered sample, resulting in rapid changes of the estimated parameter. By using a very large NVR an almost perfect model fit can be achieved; then, however, the estimated SDP model is sensitive to data outliers and anomalies - this is contra-productive if typical, systematic seasonal behaviour is to be identified to derive model structures for predicting future system behaviour (Young, 2000, 2001; Young et al., 2001). The NVR values in this study are optimized from the data via maximum likelihood prediction error decomposition as proposed by Young and Pedegral (1999) and implemented in the "Captain Toolbox". The "Captain Toolbox" also provides uncertainty bounds (standard errors) of the fits and of the time-varying parameter estimates, which are an important criterion when evaluating the estimated state-dependencies.

In this study, DLR is applied to estimate the evaporative fraction, $\mathrm{EF}[-]$, from time series of latent and sensible heat fluxes with the aim to better capture its seasonal variations and reduce the impact of short term fluctuations by noise effects:

$\lambda E(t)=\mathrm{EF}(t) \cdot(\lambda E(t)+H(t))+\zeta(t)$

with $t$ being the daily time steps [d]. The sum of the latent heat flux, $\lambda E\left[\mathrm{MJ} \mathrm{m}^{-2} \mathrm{~d}^{-1}\right]$, and the sensible heat flux, $H$ $\left[\mathrm{MJ} \mathrm{m}^{-2} \mathrm{~d}^{-1}\right]$, is assumed to represent the available energy at the land surface. It shall be noted that, strictly speaking, the error series $\zeta$ in this and all the following DLR and SDP equations has to be given a separate subscript since it is never the same error series, but in favour of a better readability and clarity we just use the symbol $\zeta$ in all equations. An example for EF calculated by means of DLR is shown in Fig. 1a. Additionally, DLR is used to depict the seasonal evolution of the light use efficiency parameter $\epsilon$ as represented in:

$F_{\mathrm{G}}(t)=\epsilon(t) \cdot \operatorname{APAR}(t)+\zeta(t)$

where $F_{\mathrm{G}}\left[\mathrm{gC} \mathrm{m}^{-2} \mathrm{~d}^{-1}\right]$ is the flux of carbon uptake or gross primary production, and APAR $\left[\mathrm{MJ} \mathrm{m}^{-2} \mathrm{~d}^{-1}\right]$ is the absorbed photosynthetically active radiation, and $\epsilon\left[\mathrm{gC} \mathrm{MJ}^{-1}\right]$ is the time-varying light use efficiency parameter.

In contrast to DLR, the SDP estimation assumes that the regression parameters vary with a state of the considered non-linear system. This state variable, however, also varies with time (Young and Pedegral, 1999; Young, 2001, 2000; Young et al., 2001):

$y(t)=\sum_{i=1}^{n} c_{i}\left(u_{i}(t)\right) \cdot x_{i}(t)+\zeta(t)$

with $u_{i}$ being variables representing time-varying system states. In the SDP algorithm, $c_{i}$ is again assumed to evolve in a stochastic random walk process characterized by a white noise sequence with a zero mean. Each sample instant depends on the data in its vicinity in a state space in which all involved variables are sorted with respect to the state variables $u_{i}$, hence out of temporal order. As with the DLR model, the NVR value determines the weighting of adjacent samples (Jarvis et al., 2004).

With estimating the dominant behaviour of a time-varying model parameter on other variables, SDP is perfectly suited to support the derivation of appropriate model structures describing the light use efficiency from measured data. In this study, SDP is therefore used to explore the seasonal behaviour of $\epsilon$ in relation to various meteorological variables (temperature and water availability surrogates) and their combinations, which are expected to influence the seasonal evolution of $\epsilon$. An example for this is shown in Fig. 1b 

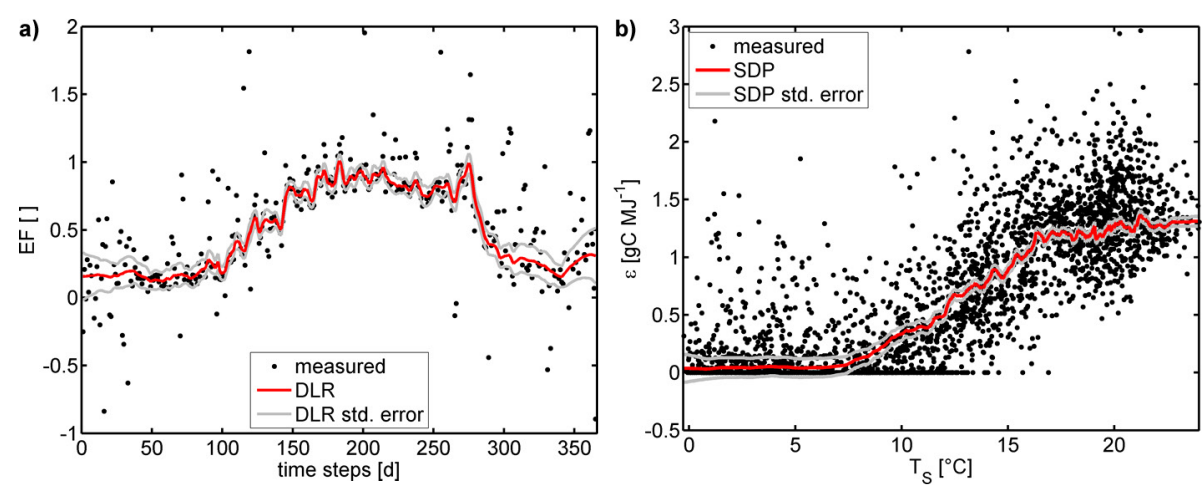

Fig. 1. (a) Example for the application of DLR to estimate the seasonal variation of the evaporative fraction, EF (see Eq. 2). Data from MMSF, 2006. (b) Example for the application of SDP to estimate the evolution of the light use efficiency $(\epsilon)$ depending on the soil temperature. $T_{\mathrm{S}}$ (see Eq. 3). Data from MMSF, 1999-2006.

for the data from the FLUXNET site MMSF; in this example, the dependency of $\epsilon$ on the upper layer $(2-10 \mathrm{~cm}$ depth) soil temperature $T_{\mathrm{S}}\left[{ }^{\circ} \mathrm{C}\right]$ as estimated with SDP is depicted:

$F_{\mathrm{G}}(t)=\epsilon\left(T_{\mathrm{S}}(t)\right) \cdot \operatorname{APAR}(t)+\zeta(t)$.

For evaluation purposes of the Jarvis-model and the model formulated in this study, the Nash-Sutcliff efficiency criterion, EC, is applied beside the typically used coefficient of determination, $r^{2}$, as squared Pearson's correlation coefficient (Legates and McCabe Jr, 1999; Krause et al., 2005), and the bias as difference of the means of measured and modelled time series. EC is defined as the sum of squared errors of the predicted $(P)$ in relation to the observed $(O)$ values normalized by the variance of $O$, and subtracted from unity (Legates and McCabe Jr, 1999; Krause et al., 2005):

$\mathrm{EC}=1-\frac{\sum_{j=1}^{N}\left(O_{j}-P_{j}\right)^{2}}{\sum_{j=1}^{N}\left(O_{j}-\bar{O}\right)^{2}}$

with $j$ running from 1 to the number of observed and modelled time steps, $N$. In contrast to $r^{2}, \mathrm{EC}$ is therewith sensitive to additive and proportional differences between measured and modelled data.

To summarize the methodological approach of this study, it shall be noted again that SDP is used as a diagnostic tool to derive dependencies of $\epsilon$ on environmental variables and therewith suitable model structures directly from the data. The outcomes of the model building study of Jarvis et al. (2004) are used as a basis to start from. The final model derived on basis of the outcome of the SDP analysis is subsequently calibrated. The parameter sensitivity is analyzed within a Monte Carlo framework. Finally, the sitespecifically optimized model parameters are brought into a climate-vegetation context to discuss the suitability of the model parameters for regionalization purposes.

\section{Model identification}

\subsection{Evaluation of the Jarvis-model}

Analysing daily flux data at two temperate forests (Harvard Forest, UMBS) with SDP, Jarvis et al. (2004) identified the light use efficiency $\epsilon_{\mathrm{J}}\left[\mathrm{gC} \mathrm{MJ}^{-1}\right]$ with respect to $F_{\mathrm{G}}$ as expressed in the following equation:

$F_{\mathrm{G}}(t)=\epsilon_{\mathrm{J}}(t) \cdot S_{0}(t)$

to follow a sigmoidal relationship with $T_{\mathrm{F}}\left[{ }^{\circ} \mathrm{C}\right]$, the timedelayed soil temperature $\left(T_{\mathrm{S}}\right)$. In the above equation, the above-canopy incident solar radiation $\left(S_{0}\left[\mathrm{MJ} \mathrm{m}^{-2} \mathrm{~d}^{-1}\right]\right)$ instead of the typically used absorbed PAR (APAR) was used by Jarvis et al. (2004); therefore, strictly speaking, $\epsilon_{\mathrm{J}}$ is not a light use efficiency and it was therefore termed "radiation capture and utilization coefficient" (Jarvis et al., 2004, p.940). The sigmoidal function of $\epsilon_{\mathrm{J}}$ was described by following equations:

$\epsilon_{\mathrm{J}}(t)=\frac{\epsilon_{\max , \mathrm{J}}}{1+\exp \left(k_{\mathrm{T}, \mathrm{J}} \cdot\left(T_{\mathrm{F}}(t)-T_{\mathrm{I}}\right)\right)}$

where

$T_{\mathrm{F}}(t)=(1-\alpha) \cdot T_{\mathrm{S}}(t)+\alpha \cdot T_{\mathrm{F}}(t-1)$.

$T_{\mathrm{I}}\left[{ }^{\circ} \mathrm{C}\right]$ is the inflection point of $\epsilon_{\mathrm{J}}$ between its minimum and maximum level $\left(\epsilon_{\max , \mathrm{J}}\left[\mathrm{gC} \mathrm{MJ}^{-1}\right]\right)$ and $k_{\mathrm{T}, \mathrm{J}}\left[{ }^{\circ} \mathrm{C}^{-1}\right]$ the rate of change of this transition. $\alpha[-]$ is the lag parameter for $T_{\mathrm{F}}$. The mean of $T_{\mathrm{S}}$-values of the first 30 days was chosen as starting point for $T_{\mathrm{F}}$. The soil temperature was filtered because the measured time series showed $\epsilon_{\max , \mathrm{J}}$ responding with delay to changes of $T_{\mathrm{S}}$. The four parameters, $\epsilon_{\max , \mathrm{J}}, T_{\mathrm{I}}$, $k_{\mathrm{T}, \mathrm{J}}$ and $\alpha$, were site-specifically calibrated by Jarvis et al. (2004) against daily data of the two study sites. The model was validated at Harvard Forest over a 6-year period. The resulting optimized parameters were shown to be well-defined.

This promising modeling approach serves as starting point for identifying a generalized model scheme applicable to a 

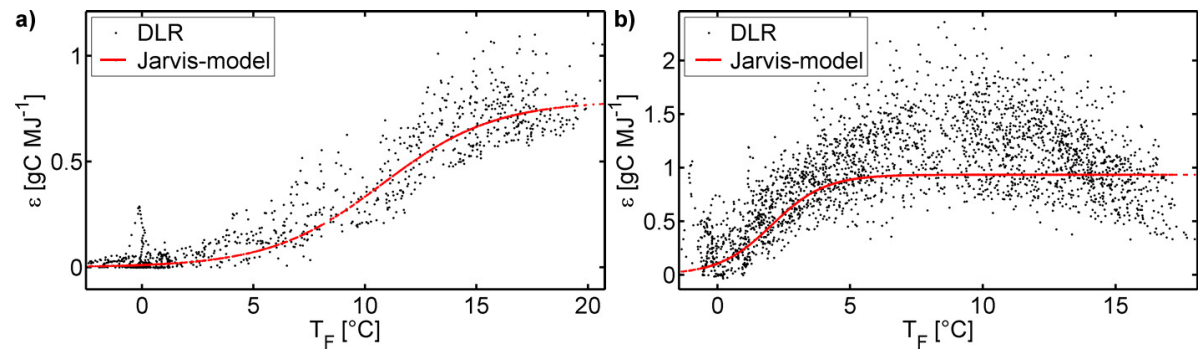

Fig. 2. $\epsilon$ obtained by DLR (see Eq. 2) as well as modelled according to Jarvis et al. (2004), both plotted vs. the delayed soil temperature $T_{\mathrm{F}}$. DLR is applied to estimate $\epsilon$ with the aim to better capture seasonal variations and reduce the impact of short term fluctuations by noise effects for diagnostic purposes. Panel (a) shows $\epsilon$ of the boreal deciduous forest Sylvania Wilderness with almost no decrease of $\epsilon$ for higher temperatures, whereas (b) represents a typical example of coniferous sites (Tharandt).

broader spectrum of vegetation and climate types. To do so, the original Jarvis-model is, as a first step, run for all study sites regardless of their vegetational and climatological characteristics to test the suitability as well as to analyse deficiencies of the model; the four constant model parameters $\left(\epsilon_{\max }\right.$, $T_{\mathrm{I}}, k_{\mathrm{T}}$ and $\alpha$ ) are optimized at each study site individually with the non-linear least squares method with regard to the measured and modelled fluxes $\left(F_{\mathrm{G}}\right)$. One difference is made compared to Jarvis et al. (2004): For better comparability with other studies, the global radiation $S_{0}$ is changed to PAR, the photosynthetically active part of $S_{0}$. This change does not impair the model applicability of the Jarvis-model since PAR is usually a quite conservative fraction of $S_{0}$ (Stigter and Musabilha, 1982), especially on a daily basis .

The Jarvis-model reproduces well the gross $\mathrm{CO}_{2}$ uptake $F_{\mathrm{G}}$ of boreal and temperate forests in terms of $r^{2}$ - and ECvalues with respect to the measured and modelled $F_{\mathrm{G}}$-values. The model performs particularly well at deciduous forests with strong seasonal dynamics as Figs. $2 \mathrm{a}$ and 3 indicate. In the former plot, the sigmoidal function describing $\epsilon$ in the Jarvis-model is compared with the measured $\epsilon$, which is for better illustration of the dominant seasonal behaviour of $\epsilon$ - somewhat noise-reduced by the application of DLR (see Eq. 3).

At forests sites in warmer C-climates and at needle-leaf forests, however, the model shows deficiencies in the temperature dependency of $\epsilon$ : The model is not able to capture the decrease of $\epsilon$ at high temperatures (Fig. 2b), which is not surprising considering the sigmoidal form of the function. $r^{2}$ - and EC-values with regard to the measured and modelled $F_{\mathrm{G}}$ time series are quite satisfying for most forests, though (Fig. 3). However, a comparison with $\epsilon$ such as shown in Fig. $2 b$ reveals that these moderate to good model performances are often just a result of the fact that PAR itself explains a large variation of $F_{\mathrm{G}}$ and, furthermore, a result of the nature of the parameter optimization procedure, which - up to a certain degree - counterbalances shortcomings of model formulations; particularly, $\alpha$ seems to compensate inappropriate model structures. $F_{\mathrm{G}}$ of forest sites experiencing hot summers as well as most grasslands cannot be simulated

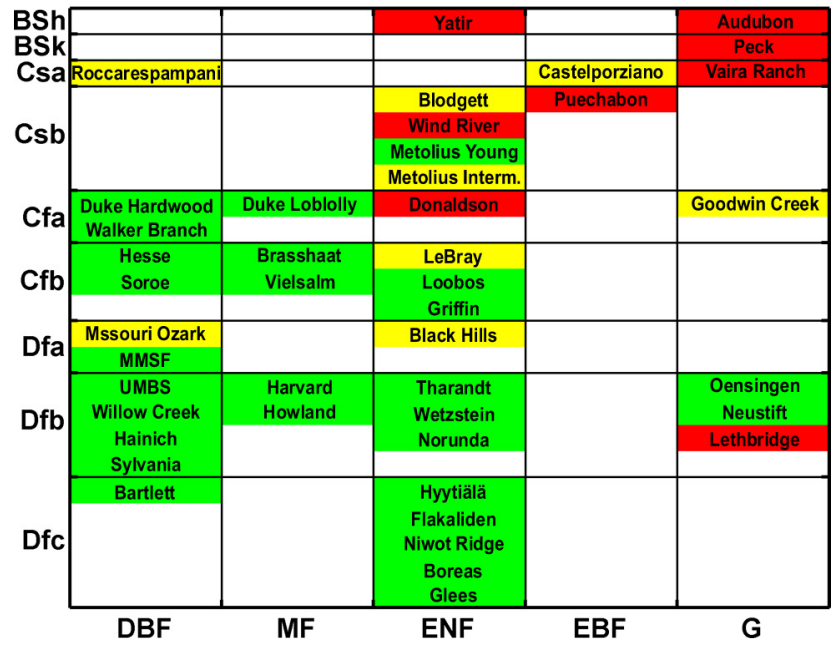

Fig. 3. Study sites in a vegetation-climate matrix; within one class, the sites are ranked according to their mean temperature from top to down. The performance of the Jarvis et al. (2004) model is indicated in 3 categories: good (green, $r^{2}>0.8$ ), moderate (yellow) bad (red, $r^{2}<0.5$ ). Koeppen-Geiger-climate classes: steppe climate (BS), temperate (C), continental (D); summer dry (s), fully humid (f); hot (h), cold in winter (k); hot summer (a), warm summer (b), cool summer (c), cold winter (d); vegetation classes: deciduous broadleaf forest (DBF), mixed (MF), evergreen needleleaf $(\mathrm{ENF})$, evergreen broadleaf (EBF), grass $(\mathrm{G})$.

by the Jarvis-model at all, because the assumed sigmoidal temperature dependency of $\epsilon$ does not exist, letting the conclusion to be drawn that a water availability proxy is lacking. Even at the fully humid study sites analyzed by Jarvis et al. (2004), cross-correlations between the model residuals and a water availability measure were found. Consequently, not only the dependency of $\epsilon$ to $T_{\mathrm{S}}$ has to be reconsidered, but also appropriate water availability measures have to be identified and their functional relationship to $\epsilon$ has to be derived. 

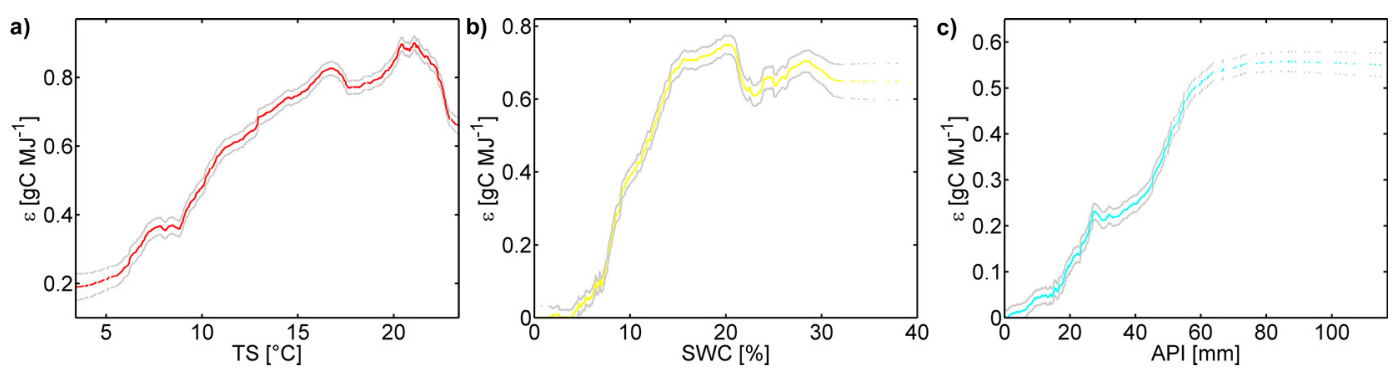

Fig. 4. $\epsilon$ depending on the major driver of $F_{\mathrm{G}}$ as obtained by a SDP-model with one state variable (Eq. 4 with $\left.N=1\right)$. State variables explaining $\epsilon$ were $T_{\mathrm{S}}$ at Duke, SWC at Vaira Ranch. API and Audubon. The grey bounds encompassing the estimated relationship represent the standard errors of the SDP estimation.

\subsection{Finding new model structures}

In order to identify the dominant state dependencies of $\epsilon$ at all study sites, SDP is applied first with $T_{\mathrm{S}}$ as state variable to systematically examine which pattern $\epsilon$ follows with regard to $T_{\mathrm{S}}$ (Eq. 5) confirming that at many sites a distinct decrease of $\epsilon$ with increasing $T_{\mathrm{S}}$ occurs (Figs. $2 \mathrm{~b}$ and $4 \mathrm{a}$ ). APAR is used instead of PAR for better comparability with other studies and because of the overwhelming evidences for the significance of the LAI or FPAR as scaling-factor for soil-vegetation-atmosphere-transfer processes (Watson, 1958; Monteith, 1977; Tucker and Sellers, 1986; Goetz and Prince, 1999; Gower et al., 1999; Lindroth et al., 2008) which cannot be compensated by other environmental variables used in the light use efficiency modeling approach.

At those sites where the Jarvis-model is not able to properly reproduce the carbon flux dynamics at all, SDP not surprisingly also fails to find a clear temperature dependency which indicates some other controlling factor on the $\epsilon$-dynamics, presumably the water availability. This failure is expressed in terms of very high standard errors of the SDP estimations and/or a low $r^{2}$-value. SDP is therefore used to analyze several water availability measures $(W)$ as potential further controls on $\epsilon$ :

$F_{\mathrm{G}}(t)=\epsilon(W(t)) \cdot \operatorname{APAR}(t)+\zeta(t)$

including EF (see Eq. 2), the vapor pressure deficit (VPD $[\mathrm{kPa}])$, the top-layer $(1-15 \mathrm{~cm}$ depth) soil water content (SWC [\%], Fig. 4b), and the antecedent precipitation index (API [mm], Fig. 4c). Besides API, these variables have demonstrated before to significantly affect gross primary production and are frequently used in light use efficiency models as moisture availability indicator (Potter et al., 1993; Prince et al., 1995; Heinsch et al., 2006; Yuan et al., 2007; Mäkelä et al., 2008). API is calculated by a weighted sum of daily precipitation values $(P[\mathrm{~mm}])$ in a time window $Z$ [d] before the current time step $t$ [d] (Linsley et al., 1982; Samaniego-Eguiguren, 2003):

$\operatorname{API}(t)=\sum_{d=0}^{Z} \kappa^{-d} \cdot P(t)^{t-d}$ where $d$ denotes the number of time steps before the current step $t$ and $\kappa[-]$ is a recession constant commonly ranging between 0.85 and 0.98 (Chow, 1964). In this study, a lower boundary of 0.90 was chosen for forests and a lower boundary of 0.88 for grasslands; the upper boundary was retained. A cosinus function is chosen such, that $\kappa$ varied between these extremes with the lowest value of $\kappa$ in summer and the highest in winter to take the higher recession of precipitation events in summer due to a higher evapotranspiration into account. Indeed, in several cases the SDP-analysis shows a distinct dependency on the water availability state variables (Fig. 4b and c).

At most sites, however, neither the temperature nor a water availability proxy alone can explain the evolution of $\epsilon$ or $F_{\mathrm{G}}$, respectively, satisfyingly. Therefore, a dimension is added to the SDP model and a two-dimensional SDP regression (see Eq. 4) is applied

$F_{\mathrm{G}}(t)=c_{1}\left(T_{\mathrm{S}}(t)\right) \cdot \operatorname{APAR}(t)+c_{2}(W(t)) \cdot \operatorname{APAR}(t)+\zeta(t)$

or respectively

$F_{\mathrm{G}}(t)=\left(c_{1}\left(T_{\mathrm{S}}(t)\right)+c_{2}(W(t))\right) \cdot \operatorname{APAR}(t)+\zeta(t)$

with

$c_{1}\left(T_{\mathrm{S}}(t)\right)+c_{2}(W(t))=\epsilon(t)$

using $T_{\mathrm{S}}$ and one of the mentioned water availability proxies. APAR is chosen instead of $S_{0}$ as used in the Jarvis et al. (2004) study for better comparability with other studies and because of the overwhelming evidences for the significance of the leaf area index or FPAR as scaling-factor for soil-vegetation-atmosphere-transfer processes (Watson, 1958; Monteith, 1977; Tucker and Sellers, 1986; Goetz and Prince, 1999; Gower et al., 1999; Lindroth et al., 2008), an explanatory power and intrinsic scaling factor which cannot be compensated by other environmental variables used in the light use efficiency model approach. The model performance varies between the water availability surrogates at the study sites, but none of them delivers the best results in every case. EF, however, appears to perform most consistently throughout the sites, whereas the use of API tends to 
lead to somewhat higher uncertainties, i.e. the related parameter estimations are less uniquely identifiable compared to the other state variables. The nonparametric relationship between $\epsilon_{\max }$ and $T_{\mathrm{S}}$ in the two-dimensional SDP estimation either has a sigmoidal form, or it can be described by a (sigmoidal) peak function (Fig. 5a), or no clear relationship can be identified at all (Fig. 5c). If a clear relationship between $\epsilon$ and the water availability state variable exists - as in the majority of cases - it usually shows a threshold-like behaviour as demonstrated exemplarily in Fig. 5b and 5d.

\subsection{Formulating the generalized model}

To overcome the applicability restrictions of the basic model with the lessons learned in the SDP analysis, the sigmoid temperature function is changed to a logistic peak function, $f_{\mathrm{T}}$, which enables a decrease of $\epsilon$ with increasing temperatures after a sigmoidal shift from the minimum to the maximum level:

$f_{\mathrm{T}}=\frac{4 \cdot \exp \left(-\left(T_{\mathrm{S}}-T_{\mathrm{opt}}\right) / k_{\mathrm{T}}\right)}{1+\exp \left(-\left(T_{\mathrm{S}}-T_{\mathrm{opt}}\right) / k_{\mathrm{T}}\right)^{2}}$

with $k_{\mathrm{T}}\left[{ }^{\circ} \mathrm{C}^{-1}\right]$ being the rate of change and $T_{\mathrm{opt}}\left[{ }^{\circ} \mathrm{C}\right]$ being the temperature at which the function reaches its maximum.

To allow for the effect of water availability fluctuations, a sigmoid function is used since SDP shows the tendency that at very low and very high values of the respective water availability proxies $W$ (EF, SWC, API and VPD) there is no change of the influence on $\epsilon$; this behaviour is evident in the one-dimensional SDP estimation (Fig. 4b and c) and gets even more obvious when taking additively both temperature and moisture in one SDP-model into account (Fig. 5). The function allowing for the influence of $W$ on $\epsilon_{\max }, f_{\mathrm{W}}$, is therefore chosen to be a sigmoid function:

$f_{\mathrm{W}}=\frac{1}{1+\exp \left(k_{\mathrm{W}} \cdot\left(W-W_{\mathrm{I}}\right)\right)}$

with $k_{\mathrm{W}}$ being the rate of change between the minimum and maximum levels of $f_{\mathrm{W}}$ and $W_{\mathrm{I}}$ being the inflection point. The units of the parameters of this subfunction depend on the variable used for $W$; in case of the usage of EF they are consequently dimensionless. Both $f_{\mathrm{T}}$ as well as $f_{\mathrm{W}}$ are scaled between zero and unity.

To account for lag effects between the response of $\epsilon$ to temperature variations we allow again for the lag effect using the lag-parameter $\alpha$ applied to $T_{\mathrm{S}}$ (Eq. 9) as it has proven to be significant in similar light use efficiency model approaches as proposed by Mäkelä et al. $(2006,2008)$ for sites in temperate and boreal climates. However, in cases of $W$ being the main driver of $\epsilon$ as it is the case in semi-arid climates, the lag function is applied to $W$ instead of $T_{\mathrm{S}}$. In applying $\alpha$ only to the main driver, the number of free parameters is minimized, and the lag is anyway only apparent in a distinctive manner on a daily time step basis when the canopy has to
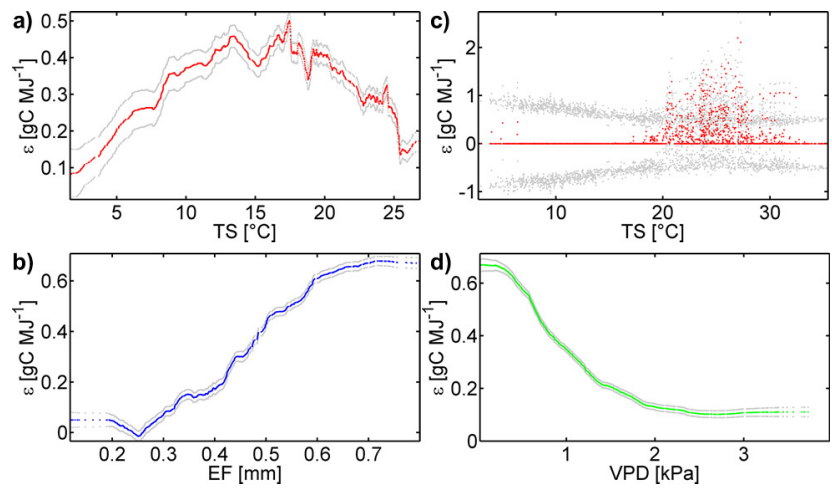

Fig. 5. $\epsilon$ as function of $T_{\mathrm{S}}$ and $\mathrm{EF}$ at the Mediterranean site Roccarespampani $(\mathbf{a}, \mathbf{b})$ and as function of $T_{\mathrm{S}}$ and VPD at the desertgrassland Audubon $(\mathbf{c}, \mathbf{d})$ as determined by the additive SDP regression (Eq. 12). The grey error bounds represent the standard errors of the SDP estimation.

regenerate and redevelop green tissue after a dormant period; and these periods are largely determined by the main driver such as the temperature in temperate and boreal climates and a moisture proxy in semi-arid climates.

The final model is formulated as follows:

$F_{\mathrm{G}}=\epsilon_{\max } \cdot\left(p \cdot f_{\mathrm{T}}+(1-p) \cdot f_{\mathrm{W}}\right) \cdot \mathrm{APAR}$

where $p$ is a dimensionless parameter scaling the subfunction to a range between zero and unity. If both temperature conditions and water availability are optimal, $\epsilon_{\max }$ is reached. If no humidity dependency can be detected, because there is always enough water available, and $\epsilon$-variations can be explained by the temperature, $p$ approaches 1 and the second term approaches zero, and vice versa. $1-p$ is consequently indirectly a measure for the strength of the water availability influence on a vegetation stand. It is therefore an interesting site-specific parameter, particularly against the background of a subsequent model regionalization.

\section{Model calibration and evaluation}

The final model formulation given by Eq. (17) and its subfuntions (Eqs. 9, 15 and 16) comprises seven constant model parameters including $\epsilon_{\max }, p, T_{\mathrm{opt}}, k_{\mathrm{T}}, W_{\mathrm{I}}, k_{\mathrm{W}}$, and $\alpha$. Before the final calibration, the sensitivity and variability for each of these parameters is explored. To do so, a set of 750000 Monte Carlo simulations is executed at each location allowing the seven parameters to vary randomly within predefined (bio-physiologically meaningful) ranges following a uniform distribution. Using the sum of squared errors between measured and modelled $F_{\mathrm{G}}$ as a performance criteria we identified the site specific parameters distributions of the 10000 best model runs. Distinct minima of the parameter response surface, indicating a unique identifiability, could be usually observed for the parameters $\epsilon_{\max }$ and $p$ as well as 

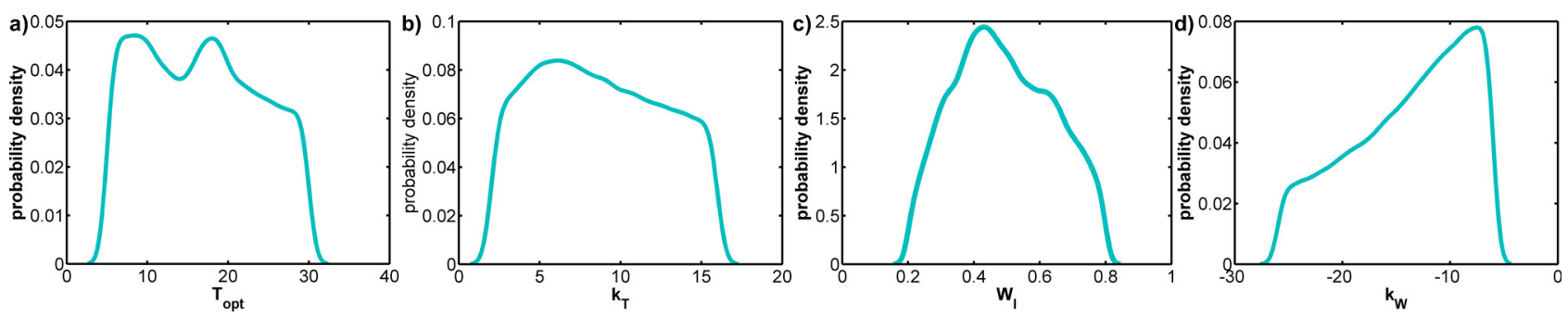

Fig. 6. Probability density functions (PDF) resulting from the Monte Carlo sensitivity study $(N=750000)$ for the proposed model in which all seven constant model parameters could vary freely. The PDFs are drawn for the best solutions (1\%) over all sites (with regard to the sum of squared errors between measured and modelled $F_{\mathrm{G}}$ time series) for the four parameters of the subfunctions $\left(f_{\mathrm{T}}, f_{\mathrm{W}}\right): T_{\mathrm{opt}}(\mathbf{a}), k_{\mathrm{T}}(\mathbf{b})$, $W_{\mathrm{I}}(\mathbf{c}), k_{\mathrm{W}}(\mathbf{d})$. In the final model calibration, $k_{\mathrm{W}}$ is set constant.
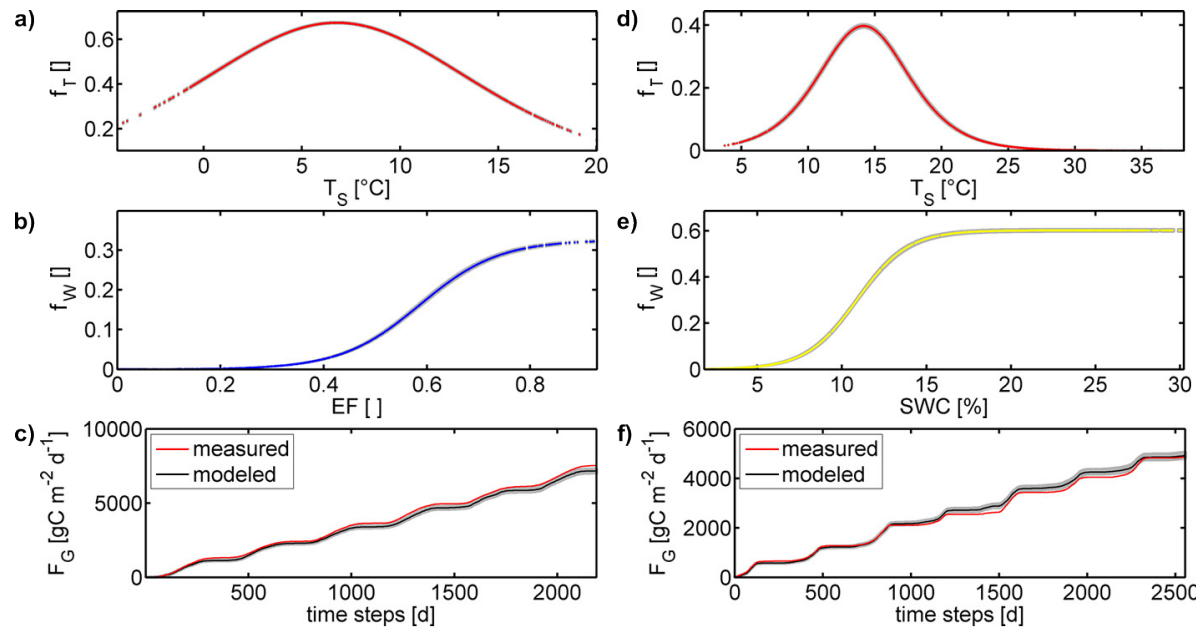

Fig. 7. $f_{\mathrm{T}}, f_{\mathrm{W}}$ and the cumulative sums of $F_{\mathrm{G}}$ with uncertainty bounds (grey) at Wetzstein (a) and Duke Forest (b). EF was used to model $F_{\mathrm{G}}$ in (a) and SWC in (b) as water availability measure. The $95 \%$ uncertainty bounds are due to the propagation of uncertainties in associated parameter estimates, as obtained by a Monte-Carlo simulation $(N=1000)$; see text for further details.

for either the parameters of $f_{\mathrm{T}}$ or that of $f_{\mathrm{W}}$, here dependent on the dominant control (temperature or water availability, see below). Analysing the $1 \%$ best solutions of all sites altogether reveals that the parameters leading to the best solutions cover a wide range within the assigned upper and lower boundaries. The respective probability distribution functions (PDF) for the seven parameters are drawn; the PDFs for the parameters of the subfunctions are depicted in Fig. 6. The PDF of the parameter $k_{\mathrm{W}}$ shows the sharpest peak, thus most of the best values at all sites are located in a relatively narrow range (Fig. 6d). Therefore, to avoid over-parameterization of the model we treated $k_{\mathrm{W}}$ constant at the median of all the best $k_{\mathrm{W}}$-values and only the remaining six parameters, $\epsilon_{\max }$, $p, T_{\mathrm{opt}}, k_{\mathrm{T}}, W_{\mathrm{I}}$ and $\alpha$ are calibrated. The model calibration is performed separately for each candidate for the water availability proxy $W$ (EF, SWC, API and VPD). The calibration is carried out using the Matlab nonlinear least-square optimization routine "Isqnonlin" which applies a subspace trustregion method and is based on the interior-reflective Newton method as described in Coleman and Li (1994).
The calibration performed well for all model runs: $r^{2}$ and EC-values of greater than 0.7 in most cases as well as relatively small biases indicate the ability of the model to reproduce $F_{\mathrm{G}}$-fluxes. The parameters are generally well defined (see Table 2). Examples of $f_{\mathrm{T}}$ and $f_{\mathrm{W}}$ as well as the resulting cumulative sums of $F_{\mathrm{G}}$ in comparison with measured cumulative sums are shown in Fig. 7 with their $95 \%$ confidence intervals caused by the propagation of the uncertainties in the associated parameter estimates as obtained by a MonteCarlo simulation $(N=1000)$; for details see e.g. Thornley and Johnson (2002). These uncertainty bounds are well bracketing measured cumulative $F_{\mathrm{G}}$-data. The minimal and maximal bias for all sites and models runs is -0.23 and $0.55 \mathrm{gC} \mathrm{m}^{-2} \mathrm{~d}^{-1}$, respectively, with positive biases occurring more frequently. For all model runs $r^{2}$ ranges between 0.4 and 0.93. The model with EF as moisture surrogate resulted in a mean $r^{2}$ of 0.85 with a standard deviation of 0.10 . The respective values for the other model runs are 0.84 and 0.08 for SWC, 0.83 and 0.11 for VPD, and 0.82 and 0.11 for API; thus, the model with EF performed best. 
Table 2. Optimized constant model parameters with their 95\% confidence intervals (in brackets) and model accuracy measures coefficient of determination $r^{2}$ and efficiency criterion EC with respect to the measured and modelled $F_{\mathrm{G}}$-time series. Full site names can be found in Table 1 .

\begin{tabular}{|c|c|c|c|c|c|c|c|c|}
\hline Name & $\epsilon_{\max }$ & $p$ & $T_{\mathrm{opt}}$ & $k_{\mathrm{T}}$ & $W_{\mathrm{I}}$ & $\alpha$ & $r^{2}$ & $\mathrm{EC}$ \\
\hline US-Blk & $0.95(0.01)$ & $0.89(0.04)$ & $11.60(0.08)$ & $6.58(0.23)$ & $0.24(0.05)$ & $0.29(0.04)$ & 0.78 & 0.78 \\
\hline US-Blo & $0.82(0.00)$ & $0.52(0.01)$ & $5.59(0.09)$ & $5.59(0.10)$ & $0.45(0.00)$ & $0.91(0.00)$ & 0.74 & 0.73 \\
\hline CA-Man & $0.78(0.00)$ & $0.30(0.01)$ & $8.91(0.09)$ & $4.01(0.11)$ & $0.29(0.00)$ & $0.05(0.05)$ & 0.85 & 0.84 \\
\hline US-SP3 & $1.07(0.01)$ & $0.44(0.02)$ & $17.99(0.13)$ & $6.01(0.20)$ & $0.58(0.01)$ & $0.97(0.00)$ & 0.44 & 0.27 \\
\hline SE-Fla & $0.89(0.01)$ & $0.66(0.01)$ & $5.00(0.14)$ & $6.05(0.17)$ & $0.41(0.01)$ & $0.00(0.24)$ & 0.85 & 0.85 \\
\hline US-GLE & $0,86(0.01)$ & $0.79(0.01)$ & $10.20(0.08)$ & $5.12(0.08)$ & $0.47(0.01)$ & $0.32(0.02)$ & 0.88 & 0.88 \\
\hline UK-Gri & $1.64(0.01)$ & $0.98(0.01)$ & $8.59(0.44)$ & $9.87(0.77)$ & $0.42(0.16)$ & $0.00(0.42)$ & 0.89 & 0.85 \\
\hline Fl-Hyy & $1.16(0.01)$ & $0.55(0.00)$ & $7.90(0.05)$ & $4.87(0.04)$ & $0.54(0.00)$ & $0.61(0.02)$ & 0.92 & 0.92 \\
\hline FR-LBr & $1.13(0.01)$ & $0.62(0.01)$ & $12.41(0.20)$ & $7.07(0.21)$ & $0.64(0.01)$ & $0.00(0.10)$ & 0.76 & 0.75 \\
\hline NL-Loo & $1.66(0.01)$ & $0.63(0.00)$ & $6.70(0.27)$ & $9.27(0.25)$ & $0.62(0.00)$ & $0.00(0.13)$ & 0.87 & 0.83 \\
\hline US-Me2 & $0.92(0.00)$ & $0.57(0.01)$ & $12.94(0.08)$ & $7.94(0.12)$ & $0.32(0.01)$ & $0.07(0.05)$ & 0.85 & 0.85 \\
\hline US-Me5 & $0.82(0.01)$ & $0.41(0.01)$ & $13.30(0.08)$ & $4.49(0.13)$ & $0.32(0.01)$ & $0.00(0.04)$ & 0.84 & 0.84 \\
\hline US-NR1 & $0.82(0.00)$ & $0.59(0.01)$ & $8.52(0.04)$ & $3.86(0.05)$ & $0.44(0.00)$ & $0.00(0.04)$ & 0.84 & 0.84 \\
\hline SE-Nor & $0.95(0.01)$ & $0.60(0.01)$ & $7.84(0.20)$ & $9,27(0.23)$ & $0.42(0.00)$ & $0.00(0.28)$ & 0.85 & 0.85 \\
\hline DE-Tha & $1.93(0.01)$ & $0.57(0.00)$ & $8.11(0.05)$ & $4.25(0.04)$ & $0.53(0.00)$ & $0.00(0.04)$ & 0.88 & 0.87 \\
\hline DE-Wet & $1.82(0.01)$ & $0.67(0.00)$ & $6.78(0.05)$ & $4.76(0.03)$ & $0.59(0.00)$ & $0.00(0.02)$ & 0.89 & 0.88 \\
\hline US-Wrc & $0.98(0.02)$ & $0.82(0.02)$ & $5.77(0.09)$ & $5.64(0.05)$ & $0.71(0.02)$ & $0.00(0.03)$ & 0.70 & 0.65 \\
\hline IL-Yat & $1.72(0.01)$ & $0.50(0.01)$ & $7.19(0.42)$ & $7.39(0.20)$ & $0.22(0.00)$ & $0.98(0.00)$ & 0.91 & 0.91 \\
\hline US-Bar & $1.14(0.01)$ & $0.59(0.01)$ & $14.52(0.08)$ & $3.84(0.05)$ & $0.47(0.01)$ & $0.87(0.01)$ & 0.93 & 0.93 \\
\hline US-Dk2 & $1.25(0.00)$ & $0.43(0.01)$ & $14.55(0.11)$ & $5.04(0.10)$ & $0.71(0.00)$ & $0.98(0.00)$ & 0.93 & 0.93 \\
\hline DE-Hai & $1.72(0.01)$ & $0.39(0.00)$ & $11.23(0.04)$ & $2.24(0.03)$ & $0.53(0.00)$ & $0.00(0.03)$ & 0.93 & 0.93 \\
\hline FR-Hes & $1.46(0.00)$ & $0.43(0.01)$ & $13.63(0.04)$ & $2.75(0.04)$ & $0.52(0.00)$ & $0.00(0.07)$ & 0.85 & 0.85 \\
\hline US-MMS & $1.29(0.00)$ & $0.49(0.01)$ & $21.19(0.19)$ & $5.67(0.15)$ & $0.57(0.00)$ & $0.00(0.07)$ & 0.91 & 0.91 \\
\hline US-MOz & $0.95(0.00)$ & $0.56(0.00)$ & $9.63(0.26)$ & $7.33(0.16)$ & $0.59(0.00)$ & $0.98(0.00)$ & 0.92 & 0.92 \\
\hline IT-Ro1 & $1.19(0.01)$ & $0.37(0.00)$ & $15.05(0.11)$ & $4.99(0.08)$ & $0.47(0.00)$ & $0.81(0.00)$ & 0.93 & 0.93 \\
\hline DK-Sor & $1.73(0.01)$ & $0.75(0.01)$ & $12.64(0.05)$ & $3.17(0.03)$ & $0.50(0.01)$ & $0.87(0.01)$ & 0.87 & 0.87 \\
\hline US-Syv & $0.85(0.01)$ & $0.79(0.01)$ & $20.06(0.25)$ & $5.83(0.16)$ & $0.35(0.02)$ & $0.10(0.04)$ & 0.94 & 0.93 \\
\hline US-UMB & $1.07(0.00)$ & $0.71(0.01)$ & $17.42(0.06)$ & $4.17(0.05)$ & $0.57(0.01)$ & $0.41(0.02)$ & 0.96 & 0.96 \\
\hline US-WBW & $1.10(0.01)$ & $0.48(0.01)$ & $18.35(0.10)$ & $4.43(0.08)$ & $0.58(0.00)$ & $0.09(0.08)$ & 0.88 & 0.88 \\
\hline US-Wcr & $1.28(0.00)$ & $0.67(0.02)$ & $18.66(0.06)$ & $3.39(0.09)$ & $0.40(0.01)$ & $0.33(0.03)$ & 0.90 & 0.90 \\
\hline IT-Cpz & $1.25(0.01)$ & $0.14(0.01)$ & $23.40(3.39)$ & $12.00(2.78)$ & $0.37(0.00)$ & $0.95(0.00)$ & 0.77 & 0.61 \\
\hline FR-Pue & $1.03(0.00)$ & $0.60(0.00)$ & $8.51(0.10)$ & $5.69(0.05)$ & $0.43(0.00)$ & $0.84(0.01)$ & 0.79 & 0.75 \\
\hline US-Aud & $1.04(0.01)$ & $0.24(0.01)$ & $24.45(0.13)$ & $2.00(0.12)$ & $0.33(0.00))$ & $0.00(0.05)$ & 0.68 & 0.68 \\
\hline US-Goo & $1.47(0.01)$ & $0.31(0.01)$ & $23.56(0.08)$ & $2.00(0.08)$ & $0.53(0.00)$ & $0.95(0.00)$ & 0.88 & 0.87 \\
\hline CA-Let & $1.49(0.01)$ & $0.35(0.00)$ & $12.19(0.12)$ & $4.68(0.08)$ & $0.47(0.00)$ & $0.00(0.04)$ & 0.92 & 0.92 \\
\hline AT-Neu & $1.80(0.01)$ & $0.64(0.02)$ & $12.21(0.08)$ & $4.04(0.12)$ & $0.64(0.01)$ & $0.00(0.08)$ & 0.83 & 0.82 \\
\hline $\mathrm{CH}-\mathrm{Oe} 1$ & $2.25(0.01)$ & $0.54(0.01)$ & $9.27(0.17)$ & $7.56(0.14)$ & $0.78(0.00)$ & $0.00(0.07)$ & 0.88 & 0.86 \\
\hline US-FPe & $1.09(0.02)$ & $0.63(0.01)$ & $9.13(0.31)$ & $6.30(0.19)$ & $0.43(0.01)$ & $0.00(0.10)$ & 0.49 & 0.48 \\
\hline US-Var & $1.36(0.00)$ & $0.38(0.00)$ & $13.24(0.05)$ & $2.71(0.04)$ & $0.57(0.00)$ & $0.91(0.00)$ & 0.91 & 0.91 \\
\hline BE-Bra & $1.05(0.01)$ & $0.66(0.00)$ & $17.66(0.42)$ & $10.13(0.41)$ & $0.57(0.01)$ & $0.00(0.16)$ & 0.87 & 0.87 \\
\hline US-Dk3 & $1.03(0.01)$ & $0.69(0.01)$ & $16.52(0.28)$ & $12.00(0.68)$ & $0.55(0.01)$ & $0.11(0.51)$ & 0.84 & 0.82 \\
\hline US-Ha1 & $1.41(0.02)$ & $0.89(0.01)$ & $20.88(0.36)$ & $6.34(0.17)$ & $0.56(0.02)$ & $0.78(0.01)$ & 0.91 & 0.91 \\
\hline US-Ho3 & $1.32(0.01)$ & $0.28(0.00)$ & $5.00(0.06)$ & $2.00(0.05)$ & $0.31(0.00)$ & $0.00(0.09)$ & 0.88 & 0.88 \\
\hline BE-Vie & $1.09(0.01)$ & $0.92(0.01)$ & $14.81(1.61)$ & $12.00(1.60)$ & $0.37(0.03)$ & $0.98(0.00)$ & 0.87 & 0.85 \\
\hline
\end{tabular}

In the following, results are described in more detail for the model with EF instead of SWC, API and VPD as water availability proxy, since (i) the calibrations with EF resulted in the highest quality criteria with generally the lowest confidence intervals, (ii) overall, EF already performed best in the
SDP-analysis, (iii) it was often successfully employed as water availability proxy in similar studies (Kustas et al., 1994; Barr et al., 2007; Yuan et al., 2007) and proved to be superior as explaining variable for $\epsilon$ in similar analysis (Garbulsky et al., 2010), and (iv) from a regionalization point of view 

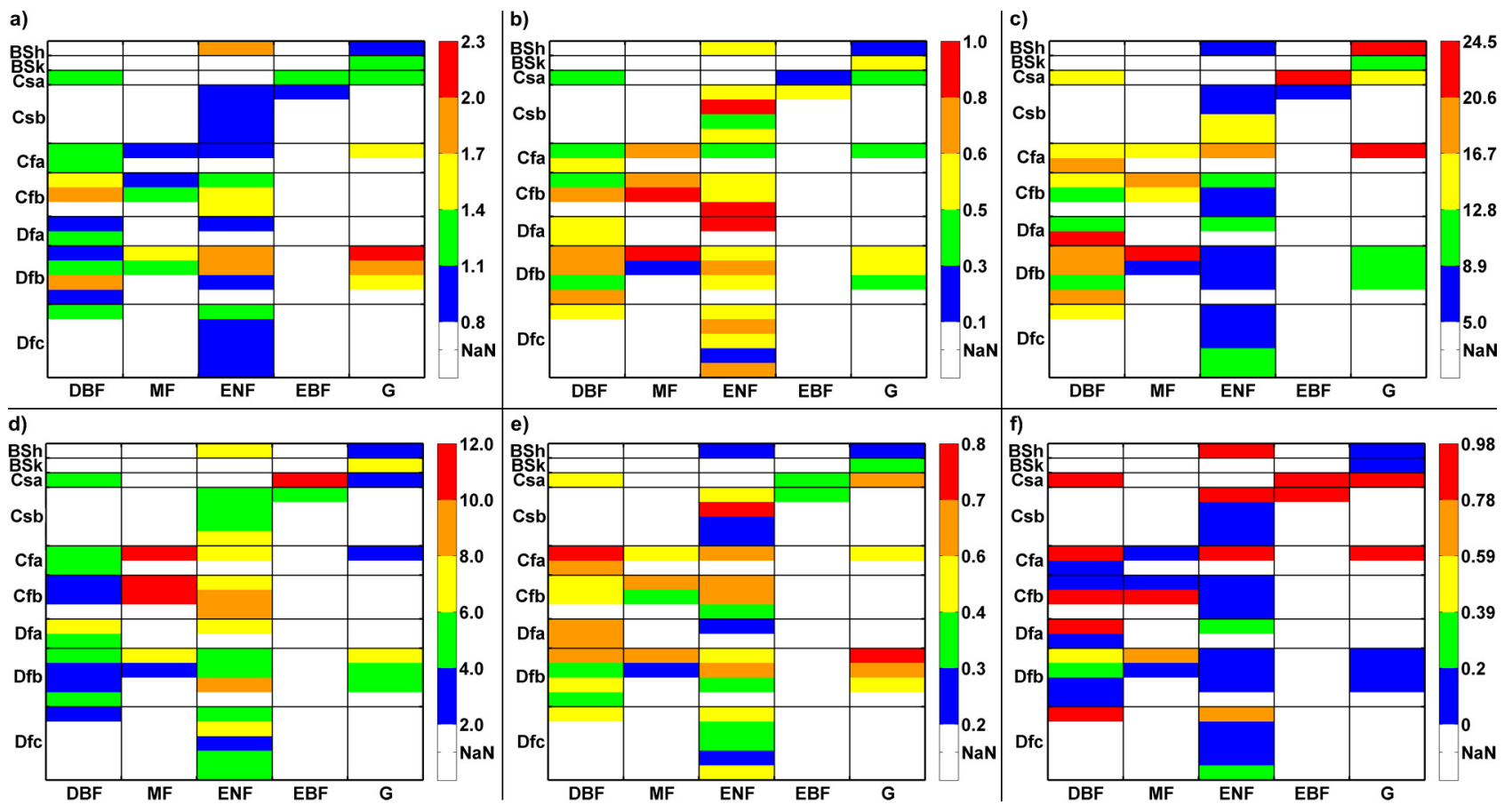

Fig. 8. The six model parameters $\epsilon_{\max }(\mathbf{a}), p(\mathbf{b}), T_{\mathrm{opt}}(\mathbf{c}), k_{\mathrm{T}}(\mathbf{d}), W_{\mathrm{I}}(\mathbf{e}), \alpha(\mathrm{f})$ in a vegetation and climate context. See Fig. 3 for an explanation of the abbreviations.

there is the potential it can be retrieved by remote sensing (Crago, 1996). Results for the other moisture surrogates are shown exemplarily (Figs. $7 \mathrm{~b}$ and 11). The resulting parameters of the optimization procedure, their confidence intervals, $r^{2}$-values and model efficiencies EC are given in Table 2 for the EF-model. All calibrated constant model parameters are shown in a climate-vegetation-matrix (Fig. 8).

The parameters of $f_{\mathrm{T}}$ have in general wider confidence intervals than $W_{\mathrm{I}}$ of $f_{\mathrm{W}}$; one reason for this certainly is the fact that $f_{\mathrm{T}}$ has two free parameters, another reason can be found in the wider range of temperature values compared to EF. However, fixation of one parameter of $f_{\mathrm{T}}$ deteriorates the model performance too much. The higher $p$, thus the more the temperature dominates the variations of $F_{G}$, and the smaller the confidence intervals of the parameters $k_{\mathrm{T}}$ and $T_{\mathrm{opt}}$ of the corresponding temperature function tend to be. Even more pronounced is the effect vice versa: The smaller $p$, thus the higher the influence of $\mathrm{EF}$, the smaller are the confidence intervals of $W_{\mathrm{I}}$ by trend (Fig. 9a). This fact can also be seen in the SSE-values resulting from a Monte Carlo sensitivity study. This was performed again for the final model with the six free model parameters: For high $p$-values, thus a high influence of the temperature on $F_{\mathrm{G}}$, the $T_{\text {opt }}$-values of the best parameter sets are typically located in a relatively narrow range, and vice versa, if $p$ is low and EF dominates $F_{\mathrm{G}}$ variations, $W_{\mathrm{I}}$ is usually better defined (Fig. 10). This observed characteristic is an advantage of the proposed model structure: the model is on the one hand flexible enough to
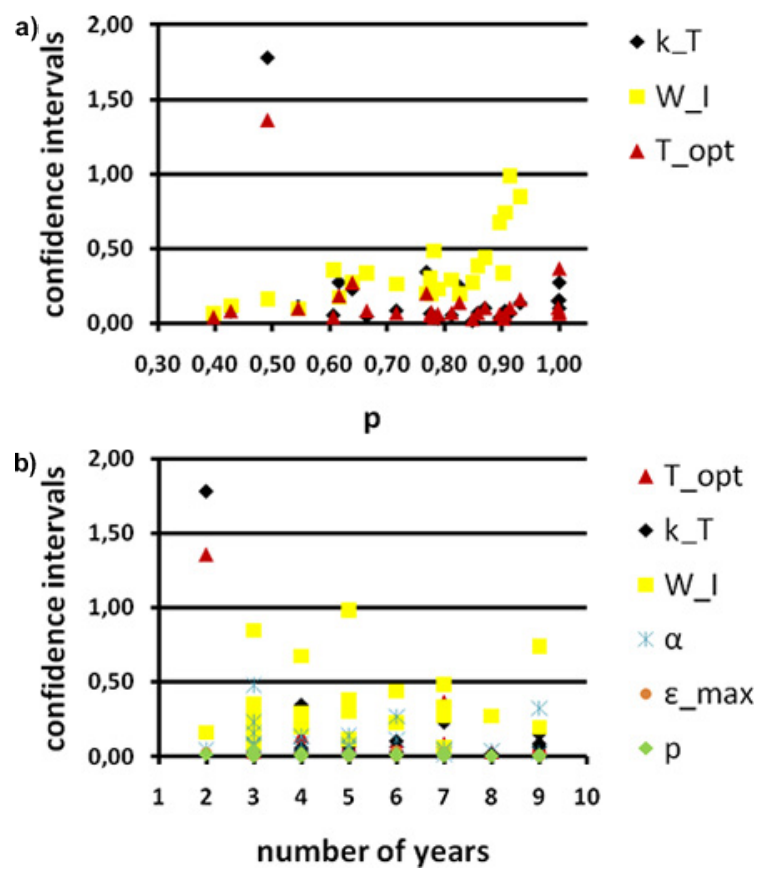

Fig. 9. 95\% confidence intervals of the calibrated model parameters $k_{\mathrm{T}}, W_{\mathrm{I}}$ and $T_{\mathrm{opt}}$ of the model subfunctions $f_{\mathrm{T}}$ and $f_{\mathrm{W}}$ (see Eqs. 1517 ) in relation to the calibrated values of $p$ (a), and the $95 \%$ confidence intervals of all model parameters in relation to the number of available measurement years used to calibrate the model (b) with SWC as water availability measure. 

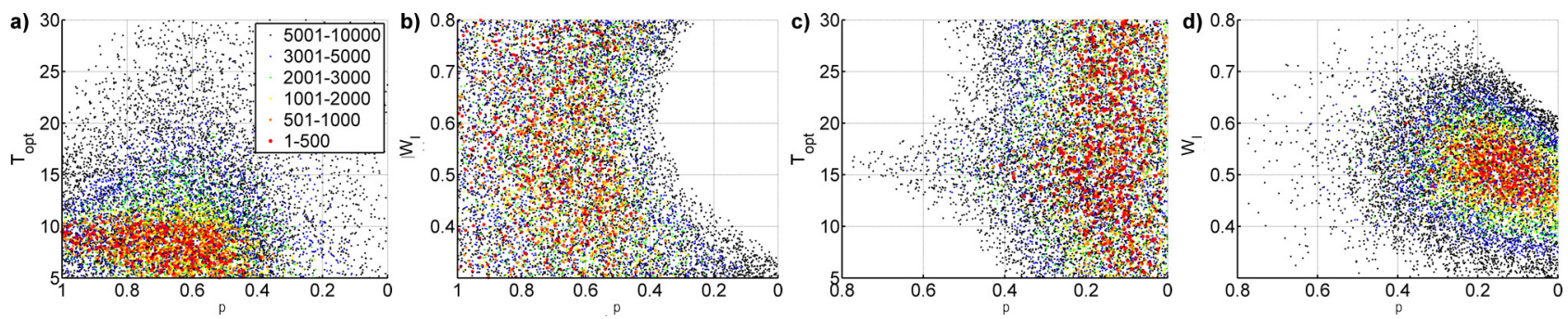

Fig. 10. The parameter space of $p$ and $T_{\mathrm{Opt}}(\mathbf{a}, \mathbf{c})$ and $p$ and $W_{\mathrm{I}}(\mathbf{b}, \mathbf{d})$ resulting from Monte Carlo simulations (10000 best parameter sets according to the sum of squared errors (SSE) between measured and modelled $F_{\mathrm{G}}$-values out of 750000 runs) shows $T_{\mathrm{opt}}$ being well defined if $p$ is high (greater contribution of $f_{\mathrm{T}}$ ) as shown for Wetzstein (a) and $W_{\mathrm{I}}$ being better defined if $p$ is low (greater contribution of $f_{\mathrm{W}}$ ) such as at Lethbridge (d). The same is true vice versa: $W_{\mathrm{I}}$ is not well defined if $f_{\mathrm{T}}$ has the greater contribution such as at Wetzstein (b). and $T_{\mathrm{opt}}$ is rather insensitive if $f_{\mathrm{W}}$ dominates such as at Lethbridge (c). The colors represent different classes with regard to the sorted SSE-values; the numbers refer to the ranking of the model results with regard to these values.

simulate daily fluxes of sites with very different characteristics, but on the other hand, gives less weight to the less influencing variables, which are at the same time prone to uncertainties in model parameter optimizations. From Fig. $9 \mathrm{~b}$ it is also obvious that with increasing length of the calibration time series the parameter confidence intervals tend to narrow, hence better results can be expected with the availability of longer measurement time series.

The model parameter $\epsilon_{\max }$ varied at forest sites between $0.78 \mathrm{gC} \mathrm{MJ}^{-1}$ at a needleleaf forest in Canada and $1.93 \mathrm{gC} \mathrm{MJ}^{-1}$ at a German needleleaf forest in a temperate climate with mild summers $(\mathrm{Cfc})$. Deciduous forests form the highest average $\epsilon_{\max }$ with a mean of $1.25 \mathrm{gC} \mathrm{MJ}^{-1}$ followed by the mixed forests $\left(1.18 \mathrm{gC} \mathrm{MJ}^{-1}\right)$ and evergreen needleleaf forests $\left(1.16 \mathrm{gC} \mathrm{MJ}^{-1}\right)$. Evergreen broadleaf forests have with $1.14 \mathrm{gC} \mathrm{MJ}^{-1}$ the lowest average $\epsilon_{\max }$ due to low values in boreal climates and those with dry summers. Regarding the climate classes with more than one forest site, $\mathrm{Cfb}$-class reveals the highest average $\epsilon_{\max }$, closely followed by Dfb; Csb and Dfc have the lowest $\epsilon_{\max }$. At grasslands sites, $\epsilon_{\max }$-values are surprisingly high: $\epsilon_{\max }$-estimations reach 2.25 at Oensingen and 1.80 at Neustift and lead to an average $\epsilon_{\max }$ of $1.50 \mathrm{gC} \mathrm{MJ}^{-1}$. The highest $\epsilon_{\max }$-values at Oensingen are attained in spring and autumn when temperatures are favourable but the amount of incoming radiation is still relatively low.

Optimized parameter values for $p$, indicating the influence of $T_{\mathrm{S}}$ and $\mathrm{EF}$, range between zero and unity and only the lowest values are omitted: $F_{\mathrm{G}}$ at the Mediterranean Roccarespampani and at Audubon, Arizona, is largely explained by EF with a $p$-value of 0.14 and 0.24 , respectively, $F_{\mathrm{G}}$ at Griffin, England, follows highly the course of temperature $(p=0.98)$. Most forest sites, however, have a medium $p$ value between 0.4 and 0.8. The low $p$-values at Hainich and especially at Boreas and Howland can be explained by a an especially high correlation between $\epsilon$ and EF in the seasonal course. At Hainich, particularly the distinct summer drought of 2003 (Reichstein et al., 2007) with a strong decrease of $\epsilon$ in late summer leads to an higher influence than at the other sites in this climate class. $p$-values greater than 0.6 are mainly clustered in the forest and fully humid climate classes, whereas $p$-estimates at forests at summery sites as well as grasslands take values in the medium to lower range.

The temperature $T_{\mathrm{opt}}$ at which the sites reach $\epsilon_{\max }$ is smaller than $14^{\circ} \mathrm{C}$ for the all needleleaf forests but the warmest fully humid study site, a result of lower average temperatures and high light use efficiencies in spring and autumn. The deciduous forests, instead, have $T_{\mathrm{opt}}$-values greater than $14^{\circ} \mathrm{C}$; here, the most efficient periods occur when the leafs have emerged following the rise of temperature in spring and before the loss of the leafs or they occur even in summer when temperatures get not too high and there is no lack of water. The grasslands located at sites with hot and semi-arid conditions are dominated by medium to high

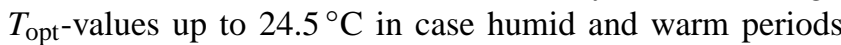
coincide. The alpine and northern Dfb grassland sites are characterized by medium to low $T_{\mathrm{opt}}$-estimates corresponding to the mild average temperatures and highest efficiencies in spring and autumn.

In addition to the information at which temperature $\epsilon_{\max }$ occurs, the parameter $k_{\mathrm{T}}$ characterizes the steepness of the temperature sensitivity in relation to the temperature range and the vegetation period. Accordingly, deciduous forests, especially at colder sites, as well as grasslands at semi-arid sites have rather low $k_{\mathrm{T}}$-values corresponding to a sharper peak of the temperature function, whereas evergreen sites particularly with a relatively small annual temperature range feature medium to high $k_{\mathrm{T}}$-values leading to a flatter and wider peak.

The parameter $W_{I}$ determining the inflection point of the $f_{\mathrm{W}}$-function takes in the most cases values between 0.3 and 0.7 , but more extreme values are represented, too. The lower $W_{\mathrm{I}}$-values cluster in the cooler climate classes and those with hot and dry summers, whereas the representatives of the upper third of the $W_{\mathrm{I}}$-range cluster in the fully humid climate classes with warm and hot summers. 

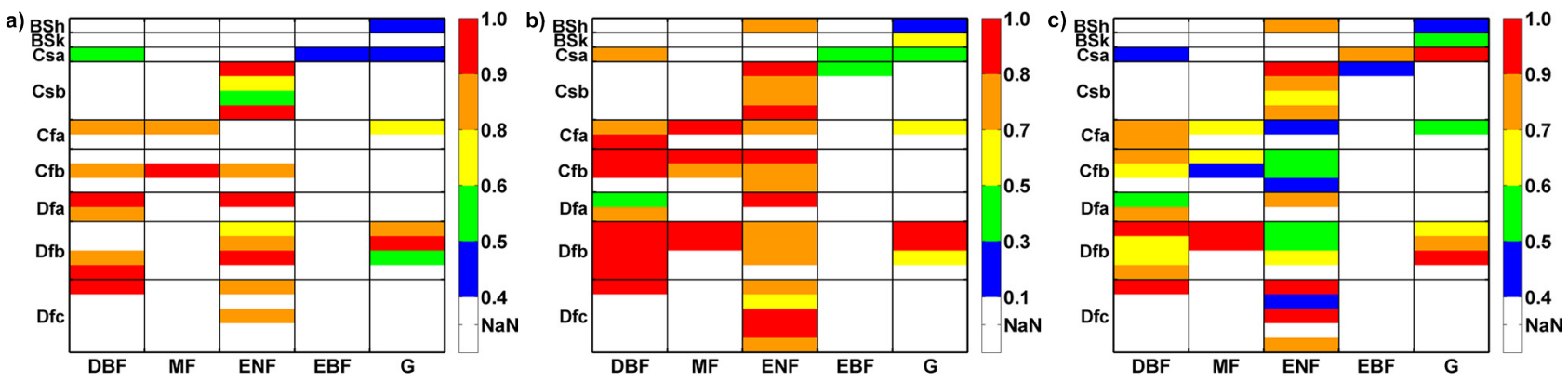

Fig. 11. Model parameter $p$ with respect to vegetation and climate classes for the model runs with SWC (a), API (b), and VPD (c) as input variables. See Fig. 3 for an explanation of the abbreviations.

The optimized values of model parameter $\alpha$, finally, are assigned to one end of the scale between zero and unity in most cases. It reaches high values near unity reflecting distinct lag processes at deciduous study sites throughout the climate classes and warmer sites of the other forest classes. However, in the most classes both extremes - lag effects and direct correspondence of $\alpha$ and the state variable, are represented. The $\mathrm{C}$-climate grasslands show delay processes whereas the grasslands in semi-arid and hot as well as continental D-climates seem to react rather promptly to the triggering variables.

Finally, the parameter $p$ for the further water availability proxies SWC, API and VPD is presented in Fig. 11. In case of SWC and API it illustrates a more homogeneous pattern of $p$-values within the vegetation-climate-matrix with lower $p$ values predominating in B- and summery climates as well as grasslands with exception of the alpine sites. More often than for SWC and API, a higher explaining power is attributed to VPD, especially at warmer coniferous sites. The highest influence of a $W$ substitute, however, is assigned to API at the desert grassland Audubon with a $p$-value of 0.15 , thus a contribution of $85 \%$.

\section{Discussion}

State dependent parameter estimation was used to determine typical non-parametric relationships between the light use efficiency and relevant state variables. An one and two-dimensional SDP estimation revealed the relationship between $\epsilon$ and $T_{\mathrm{S}}$ to follow a (sigmoidal) peak function. Limiting functions with respect to temperature have been used before: E.g. Mäkelä et al. (2008) tested a model at several coniferous study sites and used a site-specific piecewise function with a linearly increasing part and a constant value above a threshold temperature; this approach contrasts with this study, in which especially the coniferous forest sites show a relatively small efficiency amplitude during the year with the highest $\epsilon$-efficiencies at lower temperatures followed by an efficiency-decrease at higher temperatures. Yuan et al. (2007) who also modelled $F_{\mathrm{G}}$ across a broad range of conditions applied a peak function, too. They estimated the temperature optimum by non-linear optimization merging the data from all study sites. In our study, however, it is shown that highest efficiencies occur at temperatures that vary significantly across study sites. Regarding moisture availability measures, various functional forms as well as different proxies have been applied previously: E.g., Yuan et al. (2007) chose a linear relationship between $\epsilon$ and EF. Mäkelä et al. (2008) represented the relationship between $\epsilon$ and VPD by an exponential function and between $\epsilon$ and SWC by a Weibull-function or a sigmoidal function following Landsberg and Waring (1997). In this study, SDP revealed in most cases a threshold-like response of $\epsilon$ to all proxies given $\epsilon$ was sensitive to them. Overall, SDP showed a combination of the temperature and a water availability measure to be an appropriate way to model $F_{\mathrm{G}}$ if the functions describing the $\epsilon$-dependencies are flexible enough.

Indeed, the weighted additive model formulation has proven to serve as a robust approach balancing between accurate model results, the possibility to apply the model to a broad range of sites while the model parameters are well defined. Most light use efficiency models use a multiplication of $\epsilon$ down-regulating scalars (e.g., McMurtrie et al., 1994; Landsberg and Waring, 1997; Potter and Klooster, 1999; Xiao et al., 2004b; Heinsch et al., 2006; Mäkelä et al., 2008). This can lead to the parameterization of maximum $\epsilon$-values which are often not reached in reality, especially if a down-regulating variable has no strong influence at a given site, as for example the often used top-layer soil water content in a forest with deep roots can be. Furthermore, insensitive variables are prone to high calibration uncertainties of respective parameters; these are less important if their influence is relativised by a weighting factor as realized in the proposed model. Additionally, maximum $\epsilon$-values vary if a modifying scalar is added or omitted in a multiplicative approach (Mäkelä et al., 2008); the so-derived potential $\epsilon$ is in these cases a calibration artifact and not necessarily physiologically meaningful. Instead, the proposed additive model with a site-specific weighting of the variables' influence on $\epsilon$ leads to a maximum $\epsilon$ which is actually realized by the considered vegetation stands. In contrast to other 
studies (e.g. Yuan et al., 2007, 2010), this approach is based on the assumption that no universal maximum $\epsilon$ and optimal temperature exist even under ideal conditions; we assume, instead, that biochemical processes are not universal across species and that maximum $\epsilon$-values, optimal temperatures and other parameters vary between vegetation stands (Turner et al., 2003; Bradford et al., 2005; Schwalm et al., 2006; Kjelgaard et al., 2008; Stoy et al., 2008). Predictions with this model approach obviously require sufficiently long measurement time series covering optimal periods for vegetation growth. The minimum required measurement period of three years presupposed in this study can be critical in this sense (Nouvellon et al., 2000). But this restriction will become less important when FLUXNET measurement time series get longer and are made available for such calibration studies.

With the data available the calibrated parameter $\epsilon_{\max }$ varied strongly between sites as expected for the reasons stated above. Compared to maximum light use efficiency values of several studies reported in the comprehensive literature review of Goetz and Prince (1999) the calibrated values from this study appear to be somewhat greater. Compared to the average values per vegetation type obtained by Garbulsky et al. (2010) from measurement data, however, the $\epsilon_{\max }$-values tend to be smaller; the highest $\epsilon_{\max }$-value in their study was $2.01 \mathrm{gC} \mathrm{MJ}^{-1}$ compared to a value of $2.25 \mathrm{gC} \mathrm{MJ}^{-1}$ in our study. However, in both studies most vegetation types were statistically not representative; and certainly, they are significantly influenced by the choice of the FPAR data source and the processing of the measured or remotely sensed data. Interestingly, the highest $\epsilon_{\max }$-value reached at the grassland Oensingen is equal to the globally calibrated potential light use efficiency in the modeling study of Yuan et al. (2010). On basis of eddy-covariance data, Garbulsky et al. (2010) determined also grasslands as vegetation type with the highest $\epsilon_{\max }$-values among their 35 study sites. The highest forest $\epsilon_{\max }$ is found at Tharandt; in their modeling study, Mäkelä et al. (2008) observed a high potential $\epsilon_{\max }$ at Tharandt relative to other study sites, too.

The calibration of $p$ shows that temperature has indeed a high influence on $\epsilon$, especially in cooler ecosystems, as shown by numerous studies (Runyon et al., 1994; Chen et al., 1999; Nouvellon et al., 2000; Turner et al., 2003; Schwalm et al., 2006). SWC as modulating variable had the highest impact at summerdry sites and grasslands what is not surprising considering the short rooting depth and the low depth at which the SWC-measurements were made. VPD appears to influence $\epsilon$ not only in dry areas as $p$ values around 0.6 in boreal and temperate forests indicate; indeed, the interrelation between VPD and $\epsilon$ via stomatal conductance has often been shown (Wang and Leuning, 1998; Goetz and Prince, 1999; Lagergren et al., 2005; Katul et al., 2003; McCaughey et al., 2006) which contrasts with the study of Garbulsky et al. (2010) who only found a weak influence of VPD. Model runs with API do not reach the performance of the other model configurations, but at sites with strong periodic water shortage they can explain $\epsilon$-variations with the lowest $p$-values, thus the highest contribution of all $f_{\mathrm{W}}$-functions compared to the other $W$-variables. API is therefore considered as promising variable. Overall, however, the optimization procedure assigns EF most often the highest explaining capability on $\epsilon$, and model runs with EF lead to the best results. This is not surprising considering the observed correlation of $\epsilon$ and EF (Monteith and Greenwood, 1986; Schulz and Jarvis, 2004) and thus EF being an "integrator" of environmental conditions. The model with EF consequently leads to a somewhat better model performance and even allows the modeling of managed sites such as Oensingen and Neustift to a certain degree. This behaviour is supported by Stoy et al. (2009) who performed a orthonormal wavelet transformation analysis on measured $\mathrm{CO}_{2}$-fluxes and found a high importance of "endogenous" variables compared to purely meteorological variables and a strong coupling between $\lambda E$ and $F_{\mathrm{G}}$. In the analysis of Garbulsky et al. (2010), EF is also determined to be the best explaining variable of $\epsilon$. In their study, EF alone explained $\epsilon$ best and their model deteriorated when adding another variable. This contradicts with our SDP analysis and final model calibration which assigned EF a significant influence but never the only contribution to the variation of $\epsilon: p$-values of nearly unity occurred but only in one case a $p$-value of smaller than 0.2 was determined. Overall, both SDP-analysis and the model application show that both temperature and water availability influence the variation of $\epsilon$ but can not explained by one variable alone.

Throwing a glance at the distribution of the other model parameters in the climate-vegetation matrix may lead to the assumption that the optimized parameter values have no bearing on site specific characteristics. However, in the majority of cases the parameter values can be related to the vegetation class (i.e. deciduous or evergreen), the length of the vegetation period (higher or lower $k_{\mathrm{T}}$ ), the season in which $\epsilon$ gets maximal, the seasonal fluctuation of LAI and the degree of its minimization in dormant periods, the start of the vegetation period in relation to the course of temperature, the temperature amplitude, or the degree of superposition of seasonal temperature and humidity course. Noticeable are for example the differences of such similar forest sites as Howland and Harvard; both are located in the same category in the climate-vegetation matrix: mixed forests in a boreal climate with warm summers. While the mean annual temperature is somewhat lower at Harvard, maximum $\epsilon$-values at Howland occur in spring and autumn whereas the maximum $\epsilon$ at Harvard occurs rather in summer which explains the higher $T_{\mathrm{opt}}$ indicating a higher fraction of deciduous trees than at Howland; the higher $\epsilon$ at Harvard is in line with the assumptions that Harvard needs more time to develop foliage and reach $\epsilon_{\max }$.

The model performance as determined by $r^{2}$, EC and the degree of parameter uncertainty militates in favour of the proposed model particularly with regard to the wide variety 
of ecosystem characteristics of the study sites. A further study could test the benefit of integrating other drivers such as the often discussed influence of leaf nitrogen concentrations (Sinclair and Horie, 1989; Dewar, 1996; Kergoat et al., 2008) as intrinsic variable, the saturating behaviour of $\epsilon$ for high PAR values (Ruimy et al., 1995; Turner et al., 2003; Lagergren et al., 2005; Hilker et al., 2008) or the ratio of diffuse to total PAR as a proxy for cloudiness (Schwalm et al., 2006; Jenkins et al., 2007).

\section{Conclusions}

A parsimonious light use efficiency model has been set up on the basis of findings from state dependent parameter estimations. It follows the assumption that the seasonal behaviour of canopies varies between vegetation classes and its environmental conditions and the influence of explaining variables differs. It is hence assumed that no universal parameter set explaining the variation of $\mathrm{CO}_{2}$ uptake of all vegetation types in every climate class exists. The derived model is driven by incoming photosynthetically active radiation, its fraction absorbed by vegetation, the temperature and a moisture availability measure such as the evaporative fraction, the antecedent precipitation index, vapour pressure deficit or the soil moisture. Despite its simplicity it seems to capture a major proportion of the day-to-day variations in the gross $\mathrm{CO}_{2}$ uptake at 44 FLUXNET sites with largely well defined parameters. Obviously, due to its empirical nature the parameter sets will get more robust, the longer available time series are. The best agreement between model and observations are obtained using the evaporative fraction since this variable appears to incorporate more information than purely water availability. The proposed model uses variables which can be derived by remote sensing or taken from reanalysis databases like ERA-Interim from ECMWF or data from the NASA Data Assimilation Office (DAO). Additionally, the model parameters can be related to the specific environmental conditions which lead us to the conclusion that the model is suitable as basis for regionalization strategies to perform the step from the point to the area.

Acknowledgements. We gratefully acknowledge all FLUXNET investigators generously providing level 2 data for this analysis. Specifically, we thank:

- Christof Ammann of the Swiss Federal Research Station ART, Zürich, for data of Oensingen,

- Marc Aubinet of the Universitaire des Sciences Agronomiques for data of Vielsalm.

- Dennis Baldocchi of the University of California, Berkeley, for data of Vaira Ranch,

- Paul Berbigier of INRA-Bioclimatology for data of Le Bray,

- Christian Bernhofer of the TU Dresden for data of Tharandt,

- Ken Bible of the University of Washington for data of the Wind River Canopy Crane Research Facility,
- Paul Bolstad of the University of Minnesota, Bruce Cook from the NASA, Kenneth J. Davis of The Pennsylvania State University, and Ankur Desai of the University of Wisconsin for data of Sylvania Wilderness and Willow Creek,

- Alexander Cernusca and Georg Wohlfahrt of the University of Innsbruck for data of Neustift,

- Reinhart Ceulemans and all members of the Research Group of Plant and Vegetation Ecology of the Department of Biology, University of Antwerp, for data of Brasshaat,

- Peter S. Curtis of The Ohio State University for data of University of Michigan Biological Station (UMBS),

- Danilo Dragoni and HaPe Schmid of the Indiana University, funded by the US Department of Energy Terrestrial Carbon Processes program (DOE TCP), for data of Morgan Monroe State Forest (MMSF),

- Lawrence B. Flanagan of the University of Lethbridge for data of Lethbridge,

- Allen H. Goldstein of the University of California, Berkeley, for data of Blodgett,

- Andre Granier of the French National Institute for Agricultural Research for data of Hesse,

- Lianhong Gu of the Oak Ridge National Laboratory for data of Missouri Ozark,

- David Y. Hollinger of the US Forest Service for data of Howland Forest,

- Gabriel G. Katul of Duke University for data of Duke Forest (Loblolly Pine),

- Werner L. Kutsch of Max-Planck-Institute for Biogeochemistry at Jena (now at: the German Federal Research Institute for Rural Areas, Forestry and Fisheries) for data of Hainich,

- Beverly E. Law of Oregon State University for data of Metolius funded by DOE Grant no. DE-FG02-06ER64318,

- Anders Lindroth of Lund University for data of Flakaliden and Norunda,

- Timothy A. Martin of the University of Florida for data of Donaldson,

- William J. Massman of US Forest Service for data of Glees,

- Tilden Meyers of NOAA for data of the study sites Black Hills, Walker Branch, Audubon, Goodwin Creek, Peck,

- John B. Moncrieff and R. J. Clement of the School of GeoSciences, The University of Edinburgh, as part of the CarboEurope programme for data of Griffin,

- Russell Monson of the University of Colorado for Niwot Ridge,

- Eddy J. Moors of Wageningen University for data of Loobos,

- J. William Munger of Harvard University for data of Harvard Forest,

- Ram Oren, Paul Stoy, Gaby Katul, Kim Novick, Mario Siqueira and Jehnyih Juang of Duke University for data of Duke Forest (Hardwood),

- Kim Pilegaard of RisøDTU National Laboratory for data of Soroe, 
- Serge Rambal of CEFE-CNRS for data of Puechabon,

- Corinna Rebmann of the Max-Planck-Institute for Biogeochemistry at Jena for data of Wetzstein,

- Andrew D. Richardson of Harvard University for data of Bartlett,

- Riccardo Valentini of the University of Tuscia for data of Roccarespampani, Castelporziano,

- Timo Vesala of the University of Helsinki for data of Hyytiälä,

- Steve Wofsy from Harvard University (1994-2005) and Brian Amiro from University of Manitoba (2005-2008) for data of Boreas,

- Dan Yakir of the Weizmann Institute of Science for data of Yatir, Israel,

We appreciate the comments of Christof Ammann and Ankur Desai on the manuscript. The data were downloaded from the CarboEuropeIP Ecosystem Component Database supported by the European Commission, as well as from the AmeriFlux data archive at the Carbon Dioxide Information Analysis Center (CDIAC) of DOE's (US Department of Energy) Oak Ridge National Laboratory (ORNL). This study was funded by the Deutsche Forschungsgemeinschaft (DFG, Grant \#SCHU1271/4-1).

Edited by: R. Duursma

\section{References}

Acevedo, O., Moraes, O., Degrazia, G., Fitzjarrald, D., Manzi, A., and Campos, J.: Is friction velocity the most appropriate scale for correcting nocturnal carbon dioxide fluxes?, Agr. Forest Meteorol., 149, 1-10, 2009.

Allard, V., Ourcival, J. M., Rambal, S., Joffre, R., and Rocheteau, A.: Seasonal and annual variation of carbon exchange in an evergreen Mediterranean forest in southern France, Global Change Biol., 14, 714-725, doi:10.1111/j.13652486.2008.01539.x, 2008.

Ammann, C., Spirig, C., Leifeld, J., and Neftel, A.: Assessment of the nitrogen and carbon budget of two managed temperate grassland fields, Agr. Ecosyst. Environ., 133, 150-162, doi:10.1016/j.agee.2009.05.006, 2009.

Anthoni, P., Unsworth, M., Law, B., Irvine, J., Baldocchi, D., Tuyl, S., and Moore, D.: Seasonal differences in carbon and water vapor exchange in young and old-growth ponderosa pine ecosystems, Agr. Forest Meteorol. 111, 203-222, doi:10.1016/S01681923(02)00021-7, 2002.

Aubinet, M., Chermanne, B., Vandenhaute, M., Longdoz, B., Yernaux, M., and Laitat, E.: Long term carbon dioxide exchange above a mixed forest in the Belgian Ardennes, Agr. Forest Meteorol., 108, 293-315, doi:10.1016/S0168-1923(01)00244-1, 2001.

Baldocchi, D., Falge, E., Gu, L. H., Olson, R., Hollinger, D., Running, S., Anthoni, P., Bernhofer, C., Davis, K., Evans, R., Fuentes, J., Goldstein, A., Katul, G., Law, B., Lee, X. H., Malhi, Y., Meyers, T., Munger, W., Oechel, W. U. K. T. P., Pilegaard, K., Schmid, H. P., Valentini, R., Verma, S., Vesala, T., Wilson, K., and Wofsy, S.: FLUXNET: A new tool to study the temporal and spatial variability of ecosystem-scale carbon dioxide, water vapor, and energy flux densities, B. Am. Meteorol. Soc., 82, 2415-2434, 2001.

Barr, A. G., Black, T. A., Hogg, E. H., Griffis, T. J., Morgenstern, K., Kljun, N., Theede, A., and Nesic, Z.: Climatic controls on the carbon and water balances of a boreal aspen forest, 19942003, Global Change Biol., 13, 561-576, doi:10.1111/j.13652486.2006.01220.x, 2007.

Berbigier, P., Bonnefond, J., and Mellmann, P.: $\mathrm{CO}_{2}$ and water vapour fluxes for 2 years above Euroflux forest site, Agr. Forest Meteorol., 108, 183-197, doi:10.1016/S0168-1923(01)00240-4, 2001.

Beven, K. and Freer, J.: Equifinality, data assimilation, and uncertainty estimation in mechanistic modelling of complex environmental systems using the GLUE methodology, J. Hydrol., 249, 11-29, doi:10.1016/S0022-1694(01)00421-8, 2001.

Bradford, J., Hicke, J., and Lauenroth, W.: The relative importance of light-use efficiency modifications from environmental conditions and cultivation for estimation of large-scale net primary productivity, Remote Sens. Environ., 96, 246-255, doi:0.1016/j.rse.2005.02.013, 2005.

Carrara, A., Kowalski, A., Neirynck, J., Janssens, I., Yuste, J., and Ceulemans, R.: Net ecosystem $\mathrm{CO}_{2}$ exchange of mixed forest in Belgium over 5 years, Agr. Forest Meteorol., 119, 209-227, doi:10.1016/S0168-1923(03)00120-5, 2003.

Carrara, A., Janssens, I., Curiel Yuste, J., and Ceulemans, R.: Seasonal changes in photosynthesis, respiration and NEE of a mixed temperate forest, Agr. Forest Meteorol., 126, 15-31, doi:10.1016/j.agrformet.2004.05.002, 2004.

Chen, W., Black, T., Yang, P., Barr, A., Neumann, H., Nesic, Z. Blanken, P., Novak, M., Eley, J., Ketler, R., and Cuency, A.: Effects of climatic variability on the annual carbon sequestration by a boreal aspen forest, Global Change Biol., 5, 41-53, doi:10.1046/j.1365-2486.1998.00201.x, 1999.

Chow, V. T.: Handbook of applied hydrology, McGraw-Hill, New York, 1964.

Clement, R., Moncrieff, J., and Jarvis, P.: Net carbon productivity of Sitka spruce forest in Scotland, Scottish Forestry, 57, 5-10, 2003.

Coleman, T. and Li, Y.: On the convergence of reflective Newton methods for large-scale nonlinear minimization subject to bounds, Math. Programm., 76, 189-224, 1994.

Collatz, G., Ball, J., Grivet, C., and Berry, J.: Physiological and environmental regulation of stomatal conductance, photosynthesis and transpiration: a model that includes a laminar boundary layer, Agr. Forest Meteorol., 54, 107-136, doi:10.1016/01681923(91)90002-8, 1991.

Cook, B., Davis, K., Wang, W., Desai, A., Berger, B., Teclaw, R., Martin, J., Bolstad, P., Bakwin, P., Yi, C., and Heilman, W.: Carbon exchange and venting anomalies in an upland deciduous forest in northern Wisconsin, USA, Agr. Forest Meteorol., 126, 271-295, doi:10.1016/j.agrformet.2004.06.008, 2004.

Coops, N. C., Waring, R. H., and Law, B. E.: Assessing the past and future distribution and productivity of ponderosa pine in the Pacific Northwest using a process model, 3-PG, Ecol. Modell., 183, 107-124, doi:10.1016/j.ecolmodel.2004.08.002, 2005.

Cox, P., Betts, R., Jones, C., Spall, S., and Totterdell, I.: Acceleration of global warming due to carbon-cycle feedbacks in a coupled climate model, Nature, 408, 184-187, doi:10.1038/35041539, 2000. 
Cox, P. M., Huntingford, C., and Harding, R. J.: A canopy conductance and photosynthesis model for use in a GCM land surface scheme, J. Hydrol., 212-213, 79, doi:10.1016/S00221694(98)00203-0, 1998.

Crago, R.: Conservation and variability of the evaporative fraction during the daytime, J. Hydrol., 180, 173-194, doi:10.1016/00221694(95)02903-6, 1996.

Cramer, W., Bondeau, A., Woodward, F., Prentice, I., Betts, R., Brovkin, V., Cox, P., Fisher, V., Foley, J., Friend, A., Kucharik, C., Lomas, M. R., Ramankutty, N., Sitch, S., Smith, B., White, A., and Young-Molling, C.: Global response of terrestrial ecosystem structure and function to $\mathrm{CO}_{2}$ and climate change: results from six dynamic global vegetation models, Global Change Biol., 7, 357-373, doi:10.1046/j.1365-2486.2001.00383.x, 2001.

Desai, A., Bolstad, P., Cook, B., Davis, K., and Carey, E.: Comparing net ecosystem exchange of carbon dioxide between an oldgrowth and mature forest in the upper Midwest, USA, Agr. Forest Meteorol., 128, 33-55, doi:10.1016/j.agrformet.2004.09.005, 2005.

Desai, A., Richardson, A., Moffat, A., Kattge, J., Hollinger, D., Barr, A., Falge, E., Noormets, A., Papale, D., Reichstein, M., and Stauch, V. J.: Cross-site evaluation of eddy covariance GPP and RE decomposition techniques, Agr. Forest Meteorol., 148, 821-838, doi:10.1016/j.agrformet.2007.11.012, 2008.

Dewar, R. C.: The correlation between plant growth and intercepted radiation: An interpretation in terms of optimal plant nitrogen content, Ann. Bot., 78, 125-136, doi:10.1006/anbo.1996.0104, 1996.

Dolman, A., Moors, E., and Elbers, J.: The carbon uptake of a mid latitude pine forest growing on sandy soil, Agr. Forest Meteorol., 111, 157-170, doi:10.1016/S0168-1923(02)00024-2, 2002.

Falge, E., Baldocchi, D., Olson, R., Anthoni, P., Aubinet, M., Bernhofer, C., Burba, G., Ceulemans, G., Clement, R., Dolman, H., Granier, A., Gross, P., Grunwald, T., Hollinger, D., Jensen, N. O., Katul, G., Keronen, P., Kowalski, A., Lai, C. T., Law, B. E., Meyers, T., Moncrieff, J., Moors, E., Munger, J. W., Pilegaard, K., Rannik, U., Rebmann, C., Suyker, A., Tenhunen, J., Tu, K., Verma, S., Vesala, T., Wilson, K., and Wofsy, S.: Gap filling strategies for long term energy flux data sets, Agr. Forest Meteorol., 107, 71-77, doi:10.1016/S0168-1923(00)00235-5, 2001.

Falk, M. U. K. T. P., Wharton, S., and Schroeder, M.: Is soil respiration a major contributor to the carbon budget within a Pacific Northwest old-growth forest?, Agr. Forest Meteorol., 135, 269283, doi:10.1016/j.agrformet.2005.12.005, 2005.

Farquhar, G., Caemmerer, S., and Berry, J.: A biochemical model of photosynthetic $\mathrm{CO}_{2}$ assimilation in leaves of $\mathrm{C}_{3}$ species, Planta, 149, 78-90, doi:10.1007/BF00386231, 1980.

Flanagan, L.: Phenology of Plant Production in the Northwestern Great Plains: Relationships with Carbon Isotope Discrimination, Net Ecosystem Productivity and Ecosystem Respiration, Phenol. Ecosyst. Process., 2, 169-185, 2009.

Franks, S., Beven, K., Quinn, P., and Wright, I.: On the sensitivity of soil-vegetation-atmosphere transfer (SVAT) schemes: equifinality and the problem of robust calibration, Agr. Forest Meteorol., 86, 63-75, doi:10.1016/S0168-1923(96)02421-5, 1997.

Friend, A. D., Arneth, A., Kiang, N. Y., Lomas, M., Ogee, J., Rodenbeck, C., Running, S. W., Santaren, J.-D., Sitch, S., Viovy, N., Ian Woodward, F., and Zaehle, S.: FLUXNET and modelling the global carbon cycle, Global Change Biol., 13, 610-633, doi:10.1111/j.1365-2486.2006.01223.x, 2007.

Gamier, P.: Identification and estimation of continuoustime, data-based mechanistic (DBM) models for environmental systems, Environ. Model. Softw., 21, 1055-1072, doi:10.1016/j.envsoft.2005.05.007, 2006.

Gao, F., Morisette, J., Wolfe, R., Ederer, G., Pedelty, J., Masuoka, E., Myneni, R., Tan, B., and Nightingale, J.: An algorithm to produce temporally and spatially continuous MODISLAI time series, IEEE Geosci. Remote Sens. Lett., 5(60), 60-64, doi:10.1109/LGRS.2007.907971, 2008.

Garbulsky, M., Peñuelas, J., Papale, D., Ardö, J., Goulden, M., Kiely, G., Richardson, A., Rotenberg, E., Veenendaal, E., and Filella, I.: Patterns and controls of the variability of radiation use efficiency and primary productivity across terrestrial ecosystems, Global Ecol. Biogeogr., 19, 253-267, doi:10.1111/j.14668238.2009.00504.x, 2010.

Gholz, H. and Clark, K.: Energy exchange across a chronosequence of slash pine forests in Florida, Agr. Forest Meteorol., 112, 87102, doi:10.1016/S0168-1923(02)00059-X, 2002.

Goetz, S. J. and Prince, S. D.: Modelling terrestrial carbon exchange and storage: Evidence and implications of functional convergence in light-use efficiency, Adv. Ecol. Res., 28, 57-92, doi:10.1016/S0065-2504(08)60029-X, 1999.

Goldstein, A., Hultman, N., Fracheboud, J., Bauer, M., Panek, J., Xu, M., Qi, Y., Guenther, A., and Baugh, W.: Effects of climate variability on the carbon dioxide, water, and sensible heat fluxes above a ponderosa pine plantation in the Sierra Nevada (CA), Agr. Forest Meteorol., 101, 113-129, doi:10.1016/S01681923(99)00168-9, 2000.

Gough, C., Vogel, C., Schmid, H., and Curtis, P.: Controls on annual forest carbon storage: lessons from the past and predictions for the future, Bioscience, 58, 609-622, doi:10.1641/B580708, 2008.

Goulden, M. L., Winston, G. C., McMillan, A. M. S., Litvak, M. E., Read, E. L., Rocha, A. V., and Rob Elliot, J.: An eddy covariance mesonet to measure the effect of forest age on landatmosphere exchange, Global Change Biol., 12, 2146-2162, doi:10.1111/j.1365-2486.2006.01251.x, 2006.

Gower, S., Kucharik, C., and Norman, J.: Direct and indirect estimation of leaf area index, f (APAR), and net primary production of terrestrial ecosystems, Remote Sens. Environ., 70, 29-51, doi:10.1016/S0034-4257(99)00056-5, 1999.

Granier, A., Bréda, N., Longdoz, B., Gross, P., and Ngao, J.: Ten years of fluxes and stand growth in a young beech forest at Hesse, North-eastern France, Ann. Forest Sci., 65, 704-704, doi:10.1051/forest:2008052, 2008.

Grünwald, T. and Bernhofer, C.: A decade of carbon, water and energy flux measurements of an old spruce forest at the Anchor Station Tharandt, Tellus B, 59, 387-396, 2007.

Gu, L., Meyers, T., Pallardy, S., Hanson, P., Yang, B., Heuer, M., Hosman, K., Riggs, J., Sluss, D., and Wullschleger, S.: Direct and indirect effects of atmospheric conditions and soil moisture on surface energy partitioning revealed by a prolonged drought at a temperate forest site, J. Geophys. Res.-Atmos., 111, D16102, 16102, doi:10.1029/2006JD007161, 2006a.

Gu, Y. X., Belair, S., Mahfouf, J. F., and Deblonde, G.: Optimal interpolation analysis of leaf area index using MODIS data, Remote Sens. Environ., 104, 283-296, doi:10.1016/j.rse.2006.04.021, 2006 b. 
Gu, L. H., Meyers, T., Pallardy, S. G., Hanson, P. J., Yang, B., Heuer, M., Hosman, K. P., Liu, Q., Riggs, J. S., Sluss, D., and Wullschleger, S. D.: Influences of biomass heat and biochemical energy storages on the land surface fluxes and radiative temperature, J. Geophys. Res.-Atmos., 112, D02107, doi:10.1029/2006JD007425, 2007.

Heinsch, F. A., Zhao, M. S., and Running, S. W., Kimball, J. S., Nemani, R. R., Davis, K. J., Bolstad, P. V., Cook, B. D., Desai, A. R., Ricciuto, D. M., Law, B. E., Oechel, W. C., Kwon, H. J., Luo, H., Wofsy, S. C., Dunn, A. L., Munger, J. W., Baldocchi, D. D., Xu, L., Hollinger, D. Y., Richardson, A. D., Stoy, P. C., Siqueira, M. B. S., Monson, R. K., Burns, S. P., and Flanagan, L. B.: Evaluation of remote sensing based terrestrial productivity from MODIS using regional tower eddy flux network observations, IEEE T. Geosci. Remote, 44, 1908-1925, doi:10.1109/TGRS.2005.853936, 2006.

Hilker, T., Coops, N. C., Wulder, M. A., Black, T. A., and Guy, R. D.: The use of remote sensing in light use efficiency based models of gross primary production: A review of current status and future requirements, Sci. Total Environ., 404, 411-423, doi:10.1016/j.scitotenv.2007.11.007, 2008.

Hollinger, D., Aber, J., Dail, B., Davidson, E., Goltz, S., Hughes, H., Leclerc, M., Lee, J., Richardson, A., Rodrigues, C., Scott, N. A., Achuatavarier, D., and Walsh, J.: Spatial and temporal variability in forest-atmosphere $\mathrm{CO}_{2}$ exchange, Global Change Biol., 10, 1689-1706, doi:10.1111/j.1365-2486.2004.00847.x, 2004

Horn, J. E. and Schulz, K.: Post-processing analysis of MODIS leaf area index subsets, J. Appl. Remote Sens., 4, 043557, doi:10.1117/1.3524265, 2010.

Jackson, R., Jobbágy, E., Avissar, R., Roy, S., Barrett, D., Cook, C., Farley, K., Le Maitre, D., McCarl, B., and Murray, B.: Trading water for carbon with biological carbon sequestration, Science, 310, 1944, 2005.

Jarvis, A. J., Stauch, V. J., Schulz, K., and Young, P. C.: The seasonal temperature dependency of photosynthesis and respiration in two deciduous forests, Global Change Biol., 10, 939-950, doi:10.1111/j.1529-8817.2003.00743.x, 2004.

Jenkins, J. P., Richardson, A. D., Braswell, B. H., Ollinger, S. V., Hollinger, D. Y., and Smith, M. L.: Refining light-use efficiency calculations for a deciduous forest canopy using simultaneous tower-based carbon flux and radiometric measurements, Agr. Forest Meteorol., 143, 64-79, doi:10.1016/j.agrformet.2006.11.008, 2007.

Kaminski, T., Knorr, W., Rayner, P., and Heimann, M.: Assimilating atmospheric data into a terrestrial biosphere model: A case study of the seasonal cycle, Global Biogeochem. Cy., 16, 1066, doi:10.1029/2001GB001463, 2002.

Katul, G., Leuning, R., and Oren, R.: Relationship between plant hydraulic and biochemical properties derived from a steady-state coupled water and carbon transport model, Plant Cell Environ., 26, 339-350, doi:10.1046/j.1365-3040.2003.00965.x, 2003.

Keenan, T., García, R., Friend, A. D., Zaehle, S., Gracia, C., and Sabate, S.: Improved understanding of drought controls on seasonal variation in Mediterranean forest canopy $\mathrm{CO}_{2}$ and water fluxes through combined in situ measurements and ecosystem modelling, Biogeosciences, 6, 1423-1444, doi:10.5194/bg-61423-2009, 2009.
Kergoat, L., Lafont, S., Arneth, A., Le Dantec, V., and Saugier, B.: Nitrogen controls plant canopy light-use efficiency in temperate and boreal ecosystems, J. Geophys. Res.-Biogeo., 113, G04017, doi:10.1029/2007JG000676, 2008.

Kjelgaard, J. F., Heilman, J. L., McInnes, K. J., Owens, M. K., and Kamps, R. H.: Carbon dioxide exchange in a subtropical, mixed C-3/C-4 grassland on the Edwards Plateau, Texas, Agr. Forest Meteorol., 148, 953-963, doi:10.1016/j.agrformet.2008.01.006, 2008.

Knorr, W.: Annual and interannual $\mathrm{CO}_{2}$ exchanges of the terrestrial biosphere: process-based simulations and uncertainties, Global Ecol. Biogeogr., 9, 225-252, doi:10.1046/j.13652699.2000.00159.x, 2000.

Knorr, W. and Heimann, M.: Uncertainties in global terrestrial biosphere modeling, Part I: a comprehensive sensitivity analysis with a new photosynthesis and energy balance scheme, Global Biogeochem. Cy., 15, 207-225, doi:10.1029/1998GB001059, 2001a.

Knorr, W. and Heimann, M.: Uncertainties in global terrestrial biosphere modeling, Part II: global constraints for a processbased vegetation model, Global Biogeochem. Cy., 15, 227-246, doi:10.1029/1998GB001060, 2001b.

Knorr, W. and Kattge, J.: Inversion of terrestrial ecosystem model parameter values against eddy covariance measurements by Monte Carlo sampling, Global Change Biol., 11, 1333-1351, doi:10.1111/j.1365-2486.2005.00977.x, 2005.

Knyazikhin, Y., Glassy, J., Privette, J. L., Tian, Y., Lotsch, A., Zhang, Y., Wang, Y., Morisette, J. T., Votava, P., Myneni, R. B., Nemani, R. R., and Running, S. W.: MODIS Leaf Area Index (LAI) and Fraction of Photosynthetically Active Radiation Absorbed by Vegetation (FPAR) Product (MOD15) Algorithm Theoretical Basis Document, http://modis.gsfc.nasa.gov/data/atbd/ atbd_mod15.pdf (last access: January 2011), 1999.

Krause, P., Boyle, D. P., and Bäse, F.: Comparison of different efficiency criteria for hydrological model assessment, Adv. Geosci., 5, 89-97, doi:10.5194/adgeo-5-89-2005, 2005.

Kustas, W. P., Perry, E. M., Doraiswamy, P. C., and Moran, M. S.: Using satellite remote sensing to extrapolate evapotranspiration estimates in time and space over a semiarid Rangeland basin, Remote Sens. Environ., 49, 275, doi:10.1016/0034-4257(94)90022$1,1994$.

Lagergren, F., Eklundh, L., Grelle, A., Lundblad, M., Mölder, M., Lankreijer, H., and Lindroth, A.: Net primary production and light use efficiency in a mixed coniferous forest in Sweden, Plant Cell Environ., 28, 412-423, doi:10.1111/j.13653040.2004.01280.x, 2005.

Landsberg, J. J. and Waring, R. H.: A generalised model of forest productivity using simplified concepts of radiation-use efficiency, carbon balance and partitioning, Forest Ecol. Manag., 95, 209-228, doi:10.1016/S0378-1127(97)00026-1, 1997.

Law, B. E. and Waring, R. H.: Combining remote-sensing and climatic data to estimate net primary production across Oregon, Ecol. Appl., 4, 717-728, doi:10.2307/1942002, 1994.

Law, B. E., Falge, E., Gu, L., Baldocchi, D. D., Bakwin, P., Berbigier, P., Davis, K., Dolman, A. J., Falk, M., Fuentes, J. D., Goldstein, A., Granier, A., Grelle, A., Hollinger, D., Janssens, I. A., Jarvis, P., Jensen, N. O., Katul, G., Mahli, Y., Matteucci, G., Meyers, T., Monson, R., Munger, W., Oechel, W., Olson, R., Pilegaard, K., Paw, K. T., Thorgeirsson, H., Valentini, R., Verma, 
S., Vesala, T., Wilson, K., and Wofsy, S.: Environmental controls over carbon dioxide and water vapor exchange of terrestrial vegetation, Agr. Forest Meteorol., 113, 97-120, doi:10.1016/S01681923(02)00104-1, 2002.

Legates, D. and McCabe Jr., G.: Evaluating the use of "goodness-of-fit" measures in hydrologic and hydroclimatic model validation, Water Resour. Res., 35, 233-241, doi:10.1029/1998WR900018, 1999.

Leuning, R., Kelliher, F. M., Depury, D. G. G., and Schulze, E. D.: Leaf nitrogen, photosynthesis, conductance and transpiration Scaling from leaves to caopies, Plant Cell Environ., 18, 11831200, doi:10.1111/j.1365-3040.1995.tb00628.x, 1995.

Leuning, R., Cleugh, H. A., Zegelin, S. J., and Hughes, D.: Carbon and water fluxes over a temperate Eucalyptus forest and a tropical wet/dry savanna in Australia: measurements and comparison with MODIS remote sensing estimates, Agr. Forest Meteorol., 129, 151-173, doi:10.1016/j.agrformet.2004.12.004, 2005.

Lindroth, A., Lagergren, F., Aurela, M., Bjarnadottir, B., Christensen, T., Dellwik, E., Grelle, A., Ibrom, A., Johansson, T., Lankreijer, H., Launiainen, S., Laurila, T., Mölder, M., Nikinmaa, E., Pilegaard, K., Sigurdsson, B. J., and Vesala, T.: Leaf area index is the principal scaling parameter for both gross photosynthesis and ecosystem respiration of Northern deciduous and coniferous forests, Tellus B, 60, 129-142, doi:10.1111/j.16000889.2007.00330.x, 2008.

Linsley, K., Kohler, M., and Joseph, L.: Hydrology for Engineers, McGraw Hill, New York, 1982.

Ma, S., Baldocchi, D., Xu, L., and Hehn, T.: Inter-annual variability in carbon dioxide exchange of an oak/grass savanna and open grassland in California, Agr. Forest Meteorol., 147, 157171, doi:10.1016/j.agrformet.2007.07.008, 2007.

Mäkelä, A., Kolari, P., Karimaki, J., Nikinmaa, E., Peramaki, M., and Hari, P.: Modelling five years of weather-driven variation of GPP in a boreal forest, Agr. Forest Meteorol., 139, 382-398, doi:10.1016/j.agrformet.2006.08.017, 2006.

Mäkelä, A., Pulkkinen, M., Kolari, P., Lagergren, F., Berbigier, P., Lindroth, A., Loustau, D., Nikinmaa, E., Vesala, T., and Hari, P.: Developing an empirical model of stand GPP with the LUE approach: analysis of eddy covariance data at five contrasting conifer sites in Europe, Global Change Biol., 14, 92-108, doi:10.1111/j.1365-2486.2007.01463.x, 2008.

Maseyk, K., Grünzweig, J., Rotenberg, E., and Yakir, D.: Respiration acclimation contributes to high carbon-use efficiency in a seasonally dry pine forest, Global Change Biol., 14, 1553-1567, doi:10.1111/j.1365-2486.2008.01604.x, 2008.

Massman, W. and Clement, R.: Uncertainty in eddy covariance flux estimates resulting from spectral attenuation, Springer, New York, NY, USA, 2005.

McCaughey, J. H., Pejam, M. R., Arain, M. A., and Cameron, D. A.: Carbon dioxide and energy fluxes from a boreal mixedwood forest ecosystem in Ontario, Canada, Agr. Forest Meteorol., 140(79), 79-96, doi:10.1016/j.agrformet.2006.08.010, 2006.

McMurtrie, R., Gholz, H., Linder, S., and Gower, S.: Climatic factors controlling the productivity of pine stands: a model-based analysis, Ecol. Bull., 43, 173-188, 1994.
Moffat, A. M., Papale, D., Reichstein, M., Hollinger, D. Y., Richardson, A. D., Barr, A. G., Beckstein, C., Braswell, B. H., Churkina, G., Desai, A. R., Falge, E., Gove, J. H., Heimann, M., Hui, D. F., Jarvis, A. J., Kattge, J., Noormets, A., and Stauch, V. J.: Comprehensive comparison of gap-filling techniques for eddy covariance net carbon fluxes, Agr. Forest Meteorol., 147, 209-232, doi:10.1016/j.agrformet.2007.08.011, 2007.

Monteith, J. and Greenwood, D.: How do crops manipulate water supply and demand?, Philos. T. Roy. Soc. Lond. A, 316, 245259, 1986.

Monteith, J. L.: Solar radiation and productivity in tropical ecosystems, J. Appl. Ecol., 9, 747-766, 1972.

Monteith, J. L.: Climate and efficiency of crop production in Britain, Philos. T. Roy. Soc. Lond. B, 281, 277-294, 1977.

Monteith, J. L. and Unsworth, M. H.: Principles of environmental physics, 3rd edition, Chapman and Hall, New York, 2008.

Mund, M., Kutsch, W., Wirth, C., Kahl, T., Knohl, A., Skomarkova, M., and Schulze, E.: The influence of climate and fructification on the inter-annual variability of stem growth and net primary productivity in an old-growth, mixed beech forest, Tree Physiol., 30, 689-704, doi:10.1093/treephys/tpq027, 2010.

Nouvellon, Y., Begue, A., Moran, M. S., Lo Seen, D., Rambal, S., Luquet, D., Chehbouni, G., and Inoue, Y.: PAR extinction in shortgrass ecosystems: effects of clumping, sky conditions and soil albedo, Agr. Forest Meteorol., 105, 21-41, doi:10.1016/S0168-1923(00)00194-5, 2000.

ORNL DAAC - Oak Ridge National Laboratory Distributed Active Archive Center: MODIS subsetted land products, Collection 5, http://daac.ornl.gov/MODIS/modis.html, last access: 24 August, 2009.

Papale, D., Reichstein, M., Aubinet, M., Canfora, E., Bernhofer, C., Kutsch, W., Longdoz, B., Rambal, S., Valentini, R., Vesala, T., and Yakir, D.: Towards a standardized processing of Net Ecosystem Exchange measured with eddy covariance technique: algorithms and uncertainty estimation, Biogeosciences, 3, 571-583, doi:10.5194/bg-3-571-2006, 2006.

Pedregal, D., Taylor, C., and Young, P.: System identification, time series analysis and forecasting: the Captain Toolbox handbook, Tech. rep., Centre for Research on Environmental Systems and Statistics (CRES), Lancaster University, 2007.

Pilegaard, K., Mikkelsen, T., Beier, C., Jensen, N., Ambus, P., and Ro-Poulsen, H.: Field measurements of atmosphere-biosphere interactions in a Danish beech forest, Boreal Environ. Res., 8, 315-333, 2003.

Potter, C. S. and Klooster, S. A.: Dynamic global vegetation modelling for prediction of plant functional types and biogenic trace gas fluxes, Global Ecol. Biogeogr., 8, 473-488, doi:10.1046/j.1365-2699.1999.00152.x, 1999.

Potter, C. S., Randerson, J. T., Field, C. B., Matson, P. A., Vitousek, P. M., Mooney, H. A., and Klooster, S. A.: Terrestrial ecosystem production - a process model-based on global satellite and surface data, Global Biogeochem. Cy., 7, 811-841, doi:10.1029/93GB02725, 1993.

Prince, S. D., Goetz, S. J., and Goward, S. N.: Monitoring primary production from earth observing satellites, Water Air Soil Poll., 82, 509-522, doi:10.1007/BF01182860, 1995. 
Rayner, P., Scholze, M., Knorr, W., Kaminski, T., Giering, R., and Widmann, H.: Two decades of terrestrial carbon fluxes from a carbon cycle data assimilation system (CCDAS), Global Biogeochem. Cy., 19, GB2026, doi:10.1029/2004GB002254, 2005.

Rebmann, C., Zeri, M., Lasslop, G., Mund, M., Kolle, O., Schulze, E., and Feigenwinter, C.: Treatment and assessment of the $\mathrm{CO}_{2}$-exchange at a complex forest site in Thuringia, Germany, Agr. Forest Meteorol., 150, 684-691, doi:10.1016/j.agrformet.2009.11.001, 2010.

Reichstein, M., Ciais, P., Papale, D., Valentini, R., Running, S., Viovy, N., Cramer, W., Granier, A., Ogee, J., Allard, V., Aubinet, M., Bernhofer, C., Buchmann, N., Carrara, A., Grunwald, T., Heimann, M., Heinesch, B., Knohl, A., Kutsch, W., Loustau, D., Manca, G., Matteucci, G., Miglietta, F., Ourcival, J. M., Pilegaard, K., Pumpanen, J., Rambal, S., Schaphoff, S., Seufert, G., Soussana, J. F., Sanz, M. J., Vesala, T., and Zhao, M.: Reduction of ecosystem productivity and respiration during the European summer 2003 climate anomaly: a joint flux tower, remote sensing and modelling analysis, Global Change Biol., 13, 634-651, doi:10.1111/j.1365-2486.2006.01224.x, 2007.

Rosati, A. and Dejong, T. M.: Estimating photosynthetic radiation use efficiency using incident light and photosynthesis of individual leaves, Ann. Bot., 91, 869-877, doi:10.1093/aob/mcg094, 2003.

Ruimy, A., Jarvis, P. G., Baldocchi, D. D., Saugier, B., Begon, M., and Fitter, A. H.: $\mathrm{CO}_{2}$ Fluxes over Plant Canopies and Solar Radiation: A Review, in: Advances in Ecological Research, vol. 26, Academic Press, 1-68, 1995.

Running, S. and Hunt, E.: Generalization of a forest ecosystem process model for other biomes, BIOME-BGC, and an application for global-scale models, Academic Press, San Diego, CA, 141$158,1993$.

Running, S. W., Baldocchi, D. D., Turner, D. P., Gower, S. T., Bakwin, P. S., and Hibbard, K. A.: A Global Terrestrial Monitoring Network Integrating Tower Fluxes, Flask Sampling, Ecosystem Modeling and EOS Satellite Data, Remote Sens. Environ., 70, 108-127, doi:10.1016/S0034-4257(99)00061-9, 1999.

Runyon, J., Waring, R. H., Goward, S. N., and Welles, J. M.: Environmental limits of net primary production and light-use efficiency across the Oregon transect, Ecol. Appl., 4, 226-237, doi:10.2307/1941929, 1994.

Sacks, W., Schimel, D., Monson, R., and Braswell, B.: Modeldata synthesis of diurnal and seasonal $\mathrm{CO} 2$ fluxes at Niwot Ridge, Colorado, Global Change Biol., 12, 240-259, doi:10.1111/j.1365-2486.2005.01059.x, 2006.

Samaniego-Eguiguren, L.: Hydrological Consequences of Land Use/Land Cover and Climatic Changes in Mesoscale Catchments, Ph.D. thesis, Universitätsbibliothek Stuttgart, 2003.

Schimel, D., House, J., Hibbard, K., Bousquet, P., Ciais, P., Peylin, P., Braswell, B., Apps, M., Baker, D., Bondeau, A., Canadell, J., Churkina, G., Cramer, W., Denning, A. S., Field, C. B., Friedlingstein, P., Goodale, C., Heimann, M., Houghton, R. A., Melillo, J. M., Moore, B., Murdiyarso, D., Noble, I., Pacala, S. W., Prentice, I. C., Raupach, M. R., Rayner, P. J., Scholes, R. J., Steffen, W. L., and Wirth, C.: Recent patterns and mechanisms of carbon exchange by terrestrial ecosystems, Nature, 414, 169172, doi:10.1038/35102500, 2001.
Schmid, H. P., Grimmond, C. S. B., Cropley, F., Offerle, B., and $\mathrm{Su}, \mathrm{H}$. B.: Measurements of $\mathrm{CO}_{2}$ and energy fluxes over a mixed hardwood forest in the mid-western United States, Agr. Forest Meteorol., 103, 357-374, doi:10.1016/S0168-1923(00)00140-4, 2000.

Schulz, K. and Jarvis, A. J.: Environmental and biological controls on the seasonal variations in latent heat fluxes derived from flux data for three forest sites, Water Resour. Res., 40, W12501, doi:10.1029/2004WR003155, 2004.

Schulz, K., Jarvis, A., and Beven, K.: The Predictive Uncertainty of Land Surface Fluxes in Response to Increasing Ambient Carbon Dioxide, J. Climate, 14, 2551-2562, 2001.

Schwalm, C. R., Black, T. A., Arniro, B. D., Arain, M. A., Barr, A. G., Bourque, C. P. A., Dunn, A. L., Flanagan, L. B., Giasson, M. A., Lafleur, P. M., Margolis, H. A., McCaughey, J. H., Orchansky, A. L., and Wofsy, S. C.: Photosynthetic light use efficiency of three biomes across an east-west continentalscale transect in Canada, Agr. Forest Meteorol., 140, 269-286, doi:10.1016/j.agrformet.2006.06.010, 2006.

Sellers, P., Dickinson, R., Randall, D., Betts, A., Hall, F., Berry, J., Collatz, G., Denning, A., Mooney, H., Nobre, C., Sato, N., Field, C. B., and Henderson-Sellers, A.: Modeling the exchanges of energy, water, and carbon between continents and the atmosphere, Science, 275, 502-509, doi:10.1126/science.275.5299.502, 1997.

Seufert, G., Bartzis, J., Bomboi, T., Ciccioli, P., Cieslik, S., Dlugi, R., Foster, P., Hewitt, C., Kesselmeier, J., Kotzias, D., Lenz, R., Manes, F., Perez Pastor, R., Steinbrecher, R., Torres, L., Valentini, R., and Versino, B.: An overview of the Castelporziano experiments, Atmos. Environ., 31, 5-17, doi:10.1016/S13522310(97)00334-8, 1997.

Shaw, D., Franklin, J., Bible, K., Klopatek, J., Freeman, E., Greene, S., and Parker, G.: Ecological setting of the Wind River oldgrowth forest, Ecosystems, 7, 427-439, doi:10.1007/s10021004-0135-6, 2004.

Sims, D. A., Rahman, A. F., Cordova, V. D., Baldocchi, D. D., Flanagan, L. B., Goldstein, A. H., Hollinger, D. Y., Misson, L., Monson, R. K., Schmid, H. P., Wofsy, S. C., and Xu, L. K.: Midday values of gross $\mathrm{CO}_{2}$ flux and light use efficiency during satellite overpasses can be used to directly estimate eight-day mean flux, Agr. Forest Meteorol., 131, 1-12, doi:10.1016/j.agrformet.2005.04.006, 2005.

Sinclair, T. R. and Horie, T.: Leaf nitrogen, photosynthesis, crop radiation use efficiency - a review, Crop Sci., 29, 90-98, doi:10.3146/i0095-3679-20-1-11, 1989.

Siqueira, M., Katul, G., Da Sampson, P., Juang, J., McCarthy, H., and Oren, R.: Multiscale model intercomparisons of $\mathrm{CO}_{2}$ and $\mathrm{H}_{2} \mathrm{O}$ exchange rates in a maturing southeastern US pine forest, Global Change Biol., 12, 1189-1207, doi:10.1111/j.13652486.2006.01158.x, 2006.

Stauch, V. and Jarvis, A.: A semi-parametric gap-filling model for eddy covariance $\mathrm{CO}_{2}$ flux time series data, Global Change Biol., 12, 1707-1716, doi:10.1111/j.1365-2486.2006.01227.x, 2006.

Stigter, C. and Musabilha, V.: The conservative ratio of photosynthetically active to total radiation in the tropics, J. Appl. Ecol., 19, 853-858, 1982.

Stitt, M.: Rising $\mathrm{CO}_{2}$ levels and their potential significance for carbon flow in photosynthetic cells, Plant Cell Environ., 14, 741762, doi:10.1111/j.1365-3040.1991.tb01440.x, 2006. 
Stoy, P., Katul, G., Siqueira, M., Juang, J., McCarthy, H., Kim, H., Oishi, A., and Oren, R.: Variability in net ecosystem exchange from hourly to inter-annual time scales at adjacent pine and hardwood forests: a wavelet analysis, Tree Physiol., 25, 887, 2005.

Stoy, P., Palmroth, S., Oishi, A., Siqueira, M., Juang, J., Novick, K., Ward, E., Katul, G., and Oren, R.: Are ecosystem carbon inputs and outputs coupled at short time scales? A case study from adjacent pine and hardwood forests using impulse-response analysis, Plant Cell Environ., 30, 700-710, doi:10.1111/j.13653040.2007.01655.x, 2007.

Stoy, P. C., Katul, G. G., Siqueira, M. B. S., Juang, J. Y., Novick, K. A., McCarthy, H. R., Oishi, A. C., and Oren, R.: Role of vegetation in determining carbon sequestration along ecological succession in the southeastern United States, Global Change Biol., 14, 1409-1427, doi:10.1111/j.1365-2486.2008.01587.x, 2008.

Stoy, P. C., Richardson, A. D., Baldocchi, D. D., Katul, G. G., Stanovick, J., Mahecha, M. D., Reichstein, M., Detto, M., Law, B. E., Wohlfahrt, G., Arriga, N., Campos, J., McCaughey, J. H., Montagnani, L., Paw U, K. T., Sevanto, S., and Williams, M.: Biosphere-atmosphere exchange of $\mathrm{CO}_{2}$ in relation to climate: a cross-biome analysis across multiple time scales, Biogeosciences, 6, 2297-2312, doi:10.5194/bg-6-2297-2009, 2009.

Suni, T., Rinne, J., Reissell, A., Altimir, N., Keronen, P., Rannik, U., Maso, M., Kulmala, M., and Vesala, T.: Long-term measurements of surface fluxes above a Scots pine forest in Hyytiala, southern Finland, 1996-2001, Boreal Environ. Res., 8, 287-302, 2003.

Taylor, C., Pedregal, D., Young, P., and Tych, W.: Environmental time series analysis and forecasting with the Captain toolbox, Environ. Model. Softw., 22, 797-814, doi:10.1016/j.envsoft.2006.03.002, 2007.

Thornley, J. and Johnson, I.: Plant and crop modelling. A mathematical approach to plant and crop physiology, Blackburn Press, New Jersey, USA, 2002.

Tucker, C. and Sellers, P.: Satellite remote sensing of primary production, Int. J. Remote Sens., 7, 1395-1416, doi:10.1016/S03043800(99)00140-4, 1986.

Turner, D. P., Urbanski, S., Bremer, D., Wofsy, S. C., Meyers, T., Gower, S. T., and Gregory, M.: A cross-biome comparison of daily light use efficiency for gross primary production, Global Change Biol., 9, 383-395, doi:10.1046/j.13652486.2003.00573.x, 2003.

Urbanski, S., Barford, C., Wofsy, S., Kucharik, C., Pyle, E., Budney, J., McKain, K., Fitzjarrald, D., Czikowsky, M., and Munger, J.: Factors controlling $\mathrm{CO}_{2}$ exchange on timescales from hourly to decadal at Harvard Forest, J. Geophys. Res., 112, G02020, doi:10.1029/2006JG000293, 2007.

Veroustraete, F., Sabbe, H., and Eerens, H.: Estimation of carbon mass fluxes over Europe using the C-Fix model and Euroflux data, Remote Sens. Environ., 83, 376, doi:10.1016/S00344257(02)00043-3, 2002.

Wallin, G., Linder, S., Lindroth, A., Rantfors, M., Flemberg, S., and Grelle, A.: Carbon dioxide exchange in Norway spruce at the shoot, tree and ecosystem scale, Tree Physiol., 21, 969-976, 2001.

Wang, Y. and Leuning, R.: A two-leaf model for canopy conductance, photosynthesis and partitioning of available energy I: Model description and comparison with a multi-layered model, Agr. Forest Meteorol., 91, 89-111, doi:10.1016/S0168-
1923(98)00061-6, 1998.

Wang, Y., Leuning, R., Cleugh, H., and Coppin, P.: Parameter estimation in surface exchange models using nonlinear inversion: how many parameters can we estimate and which measurements are most useful?, Global Change Biol., 7, 495-510, doi:10.1046/j.1365-2486.2001.00434.x, 2001.

Watson, D.: The dependence of net assimilation rate on leaf-area index, Ann. Bot., 22, 37, 1958.

Watson, D. J.: Comparative physiological studies on the growth of field crops, 1. Variation in net assimilation rate and leaf area between species and varieties, and within and between years, Ann. Bot., 11, 41-76, 1947.

White, M., Thornton, P., Running, S., and Nemani, R.: Parameterization and sensitivity analysis of the BIOME-BGC terrestrial ecosystem model: net primary production controls, Earth Interact., 4, 1-85, 2000.

Williams, M., Schwarz, P., Law, B., Irvine, J., and Kurpius, M.: An improved analysis of forest carbon dynamics using data assimilation, Global Change Biol., 11, 89-105, doi:10.1111/j.13652486.2004.00891.x, 2004.

Wilson, T. B. and Meyers, T. P.: Determining vegetation indices from solar and photosynthetically active radiation fluxes, Agr. Forest Meteorol., 144, 160-179, doi:10.1016/j.agrformet.2007.04.001, 2007.

Wohlfahrt, G., Hammerle, A., Haslwanter, A., Bahn, M., Tappeiner, U., and Cernusca, A.: Seasonal and inter-annual variability of the net ecosystem $\mathrm{CO}_{2}$ exchange of a temperate mountain grassland: Effects of weather and management, J. Geophys. Res.-Atmos., 113, D08110, doi:10.1029/2007JD009286, 2008.

Xiao, J. F., Zhuang, Q. L., Baldocchi, D. D., Law, B. E., Richardson, A. D., Chen, J. Q., Oren, R., Starr, G., Noormets, A., Ma, S. Y., Verma, S. B., Wharton, S., Wofsy, S. C., Bolstad, P. V., Burns, S. P., Cook, D. R., Curtis, P. S., Drake, B. G., Falk, M., Fischer, M. L., Foster, D. R., Gu, L. H., Hadley, J. L., Hollinger, D. Y., Katul, G. G., Litvak, M., Martin, T. A., Matamala, R., McNulty, S., Meyers, T. P., Monson, R. K., Munger, J. W., Oechel, W. C. U. K. T. P., Schmid, H. P., Scott, R. L., Sun, G., Suyker, A. E., and Torn, M. S.: Estimation of net ecosystem carbon exchange for the conterminous United States by combining MODIS and AmeriFlux data, Agr. Forest Meteorol., 148, 18271847, doi:10.1016/j.agrformet.2008.06.015, 2008.

Xiao, X., Hollinger, D., Aber, J., Goltz, M., Davidson, E. A., Zhang, Q., and Moore, I. I. I. B.: Satellite-based modeling of gross primary production in an evergreen needleleaf forest, Remote Sens. Environ., 89, 519, doi:10.1016/j.rse.2004.08.015, 2004a.

Xiao, X., Zhang, Q., Braswell, B., Urbanski, S., Boles, S., Wofsy, S., Moore, I. I. I. B., and Ojima, D.: Modeling gross primary production of temperate deciduous broadleaf forest using satellite images and climate data, Remote Sens. Environ., 91, 256, doi:10.1016/j.rse.2004.03.010, 2004 b.

Yang, W., Shabanov, N. V., Huang, D., Wang, W., Dickinson, R. E., Nemani, R. R., Knyazikhin, Y., and Myneni, R. B.: Analysis of leaf area index products from combination of MODIS Terra and Aqua data, Remote Sens. Environ., 104, 297-312, doi:10.1016/j.rse.2006.04.016, 2006.

Young, P.: Data-based mechanistic modelling of environmental, ecological, economic and engineering systems, Environ.1 Model. Softw., 13, 105-122, doi:10.1016/S1364-8152(98)00011-5, 1998. 
Young, P.: Stochastic, dynamic modelling and signal processing: time variable and state dependent parameter estimation. IN: Nonlinear and nonstationary signal processing, 1st edition, Cambridge University Press, Cambridge, UK, 2000.

Young, P.: The Identification and Estimation of Nonlinear Stochastic Systems, in: Nonlinear Dynamics and Statistics, Birkhauser, Boston, 2001.

Young, P. and Pedegral, D.: Recursive and en-bloc approaches to signal extraction, J. Appl. Stat., 26, 103-128, doi:10.1080/02664769922692, 1999.

Young, P., McKenna, P., and Bruun, J.: Identification of non-linear stochastic systems by state dependent parameter estimation, Int. J. Control, 74, 1837-1857, doi:10.1080/00207170110089824, 2001.

Yuan, W., Liu, S., Yu, G., Bonnefond, J., Chen, J., Davis, K., Desai, A., Goldstein, A., Gianelle, D., and Rossi, F., Suyker, A. E., and Verma, S. B.: Global estimates of evapotranspiration and gross primary production based on MODIS and global meteorology data, Remote Sens. Environ., 114, 1416-1431, doi:10.1016/j.rse.2010.01.022, 2010.
Yuan, W. P., Liu, S., Zhou, G. S., Zhou, G. Y., Tieszen, L. L., Baldocchi, D., Bernhofer, C., Gholz, H., Goldstein, A. H., Goulden, M. L., Hollinger, D. Y., Hu, Y., Law, B. E., Stoy, P. C., Vesala, T., and Wofsy, S. C.: Deriving a light use efficiency model from eddy covariance flux data for predicting daily gross primary production across biomes, Agr. Forest Meteorol., 143, 189-207, doi:10.1016/j.agrformet.2006.12.001, 2007.

Zaehle, S., Sitch, S., Smith, B., and Hatterman, F.: Effects of parameter uncertainties on the modeling of terrestrial biosphere dynamics, Global Biogeochem. Cy. 19, GB3020, doi:10.1029/2004GB002395, 2005.

Zhao, M., Heinsch, F., Nemani, R., and Running, S.: Improvements of the MODIS terrestrial gross and net primary production global data set, Remote Sens. Environ., 95, 164-176, doi:10.1016/j.rse.2004.12.011, 2005. 